Award Number: W81XWH-11-2-0205

TITLE: Darton College Customized Nursing Program for the Fort Benning Community and Research Project

PRINCIPAL INVESTIGATOR: Kathryn D. Bishop

CONTRACTING ORGANIZATION: Darton College Albany, GA 31707

REPORT DATE: October 2013

TYPE OF REPORT: Final

PREPARED FOR: U.S. Army Medical Research and Materiel Command Fort Detrick, Maryland 21702-5012

DISTRIBUTION STATEMENT: Approved for Public Release; Distribution Unlimited

The views, opinions and/or findings contained in this report are those of the author(s) and should not be construed as an official Department of the Army position, policy or decision unless so designated by other documentation. 


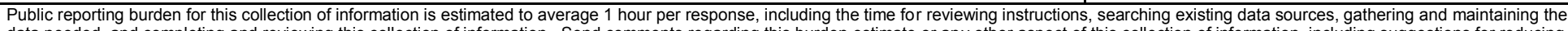

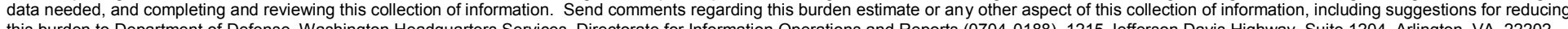

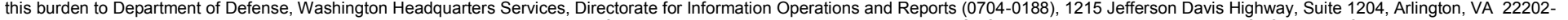

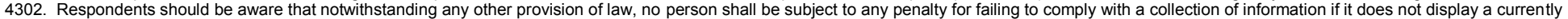
valid OMB control number. PLEASE DO NOT RETURN YOUR FORM TO THE ABOVE ADDRESS.

\begin{tabular}{|l|l|l|}
\hline 1. REPORT DATE & 2. REPORT TYPE & 3. DATES COVERED
\end{tabular} \begin{tabular}{l|l} 
October 2013 & Final \\
\hline
\end{tabular}

4. TITLE AND SUBTITLE

Darton College Customized Nursing Program for the Fort Benning Community and

Research Project

14September2011-13September2013

5a. CONTRACT NUMBER

6. AUTHOR(S)

Kathryn D. Bishop 5b. GRANT NUMBER

W81XWH-11-2-0205

5c. PROGRAM ELEMENT NUMBER

5d. PROJECT NUMBER

5e. TASK NUMBER

5f. WORK UNIT NUMBER

8. PERFORMING ORGANIZATION REPORT NUMBER

Darton College

Albany, GA 31707

9. SPONSORING / MONITORING AGENCY NAME(S) AND ADDRESS(ES)

U.S. Army Medical Research and Materiel Command

Fort Detrick, Maryland 21702-5012

12. DISTRIBUTION / AVAILABILITY STATEMENT

Approved for Public Release; Distribution Unlimited

\section{SUPPLEMENTARY NOTES}

\section{ABSTRACT}

Darton State College's Customized Nursing Programs for the Fort Benning Community are created specifically for the Fort Benning community. The Customized Nursing Program consists of two different tracks. The Traditional Hybrid Nursing program is for students who have no formal healthcare background. The Accelerated Bridge program is for LPNs, Paramedics and Army Medic 68W M6. The Customized Nursing Programs allows students to take face-to-face and online courses that are instructor led, highly interactive, and use the latest multimedia technologies. All aspects of the of the courses, services and program as being evaluated including quantitative analysis comparing the Fort Benning cohorts to the corresponding Darton College cohorts for Semester Grade Point Averages (GPA, graduating GPAs, and retention rates. In three instances one of the Fort Benning cohorts was statistically higher than the corresponding Albany cohorts, and in one instance it was the reverse. The formative evaluations have been constructive have been used to continually improve the courses, services, and programs. The student focus groups, phone interviews and online surveys produce similar responses and are overall very positive. Students are extremely positive of the program overall and the customization and especially the flexibility the programs.

15. SUBJECT TERMS- none provided

\begin{tabular}{|c|c|c|c|l|l|}
\hline \multicolumn{2}{|l|}{ 16. SECURITY CLASSIFICATION OF: } & $\begin{array}{l}\text { 17. LIMITATION } \\
\text { OF ABSTRACT }\end{array}$ & $\begin{array}{l}\text { 18. NUMBER } \\
\text { OF PAGES }\end{array}$ & $\begin{array}{l}\text { 19a. NAME OF RESPONSIBLE PERSON } \\
\text { USAMRMC }\end{array}$ \\
\cline { 1 - 2 } $\begin{array}{c}\text { a. REPORT } \\
\text { U }\end{array}$ & $\begin{array}{c}\text { b. ABSTRACT } \\
\text { C. THIS PAGE }\end{array}$ & U & UU & 35 & $\begin{array}{l}\text { 19b. TELEPHONE NUMBER (include area } \\
\text { code) }\end{array}$ \\
& & & & \\
\end{tabular}




\section{TABLE OF CONTENTS}

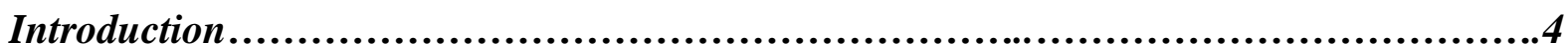

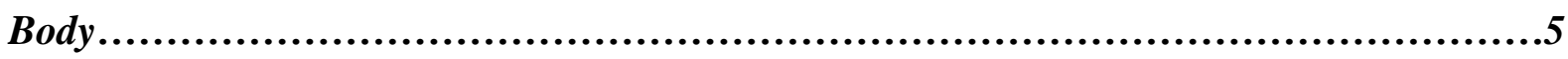

Research Accomplishments............................................................10

Reportable Outcomes...............................................................20

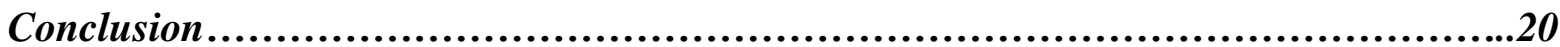

Appendices 


\section{Darton College Customized Nursing Program for the Fort Benning Community and Research}

ANNUAL REPORT

September 14, 2012 - September 13, 2013

\section{Introduction}

The Customized Nursing Programs for the Fort Benning Community project provides this community two different nursing programs: a Traditional Hybrid Nursing program and an Accelerated Bridge program for LPNs, Paramedics and Army Medics 68W M6. Research includes qualitative and quantitative methods. The participants are limited to active duty military, their dependents and employees of Fort Benning. The cohorts, their courses, and when they began are contained in the tables below arranged by semester. The evaluations are used both formative and summative. The summative research is to evaluate the quality and effectiveness of the programs as compared to companion semesters taught on the main campus at Darton State College. The first part of the report is organized around the statement of work items. Attachments provide additional details.

The chart below outlines the Customize Nursing programs for the Fort Benning Community cohorts and courses offered during this year.

First Quarter Cohorts and Courses:

\begin{tabular}{|l|l|l|l|}
\hline \multicolumn{1}{|c|}{ Cohort } & \multicolumn{1}{|c|}{$\begin{array}{c}\text { Date } \\
\text { Begun }\end{array}$} & \multicolumn{1}{c|}{ Program } & \multicolumn{1}{c|}{$\begin{array}{c}\text { Courses Fall Semester 2012 } \\
\text { (August 15 - December 11) }\end{array}$} \\
\hline $\begin{array}{l}\text { Traditional II } \\
\left(3^{\text {rd }} \text { of 5 }\right. \\
\text { semesters })\end{array}$ & $\begin{array}{l}\text { January } \\
2012\end{array}$ & Traditional Nursing Program & $\begin{array}{l}\text { Adult Health II NURS 1112 } \\
\text { Psychiatric Nursing NURS 2113 }\end{array}$ \\
\hline $\begin{array}{l}\text { Bridge II } \\
\left(4^{\text {th }} \text { of } 4\right. \\
\text { semesters })\end{array}$ & $\begin{array}{l}\text { October } \\
2011\end{array}$ & Healthcare Professional Bridge & $\begin{array}{l}\text { Adult Health III NURS 2115 } \\
\text { Graduated December 2012 }\end{array}$ \\
\hline $\begin{array}{l}\text { Bridge III }\left(1^{\text {st }}\right. \\
\text { of } 4 \\
\text { semesters })\end{array}$ & $\begin{array}{l}\text { October } \\
2012\end{array}$ & Healthcare Professional Bridge & $\begin{array}{l}\text { Fundamentals NURS 1301 } \\
\text { Psychiatric Nursing NURS 2313 }\end{array}$ \\
\hline
\end{tabular}

Second Quarter Cohorts and Courses:

\begin{tabular}{|c|c|c|c|}
\hline Cohort & $\begin{array}{l}\text { Date } \\
\text { Begun }\end{array}$ & Program & $\begin{array}{c}\text { Courses Spring Semester } 2013 \\
\text { (January 3 - May 3) }\end{array}$ \\
\hline $\begin{array}{l}\text { Traditional II } \\
\left(4^{\text {th }} \text { of } 5\right. \\
\text { semesters })\end{array}$ & $\begin{array}{l}\text { January } \\
2012\end{array}$ & Traditional Nursing Program & $\begin{array}{l}\text { Nursing Care/Women/Child } \\
\text { NURS } 2111 \\
\text { Nursing Leadership NURS } 2117\end{array}$ \\
\hline $\begin{array}{l}\text { Traditional } \\
\text { III ( } 1^{\text {st }} \text { of } 5 \\
\text { semesters })\end{array}$ & $\begin{array}{l}\text { January } \\
2013\end{array}$ & Traditional Nursing Program & $\begin{array}{l}\text { Fundamentals NURS } 1101 \\
\text { Pharmacology NURS } 1105\end{array}$ \\
\hline $\begin{array}{l}\text { Bridge III } \\
\text { (2nd of } 4 \\
\text { semesters) }\end{array}$ & $\begin{array}{l}\text { October } \\
2012\end{array}$ & Healthcare Professional Bridge & $\begin{array}{l}\text { Adult Health II NURS } 1311 \\
\text { Pharmacology NURS } 1105\end{array}$ \\
\hline
\end{tabular}


Third Quarter Cohorts and Courses:

\begin{tabular}{|c|c|c|c|}
\hline Cohort & $\begin{array}{c}\text { Date } \\
\text { Begun }\end{array}$ & Program & $\begin{array}{c}\text { Courses Summer Semester } \\
2013 \text { (May } 21 \text { - July 25) }\end{array}$ \\
\hline $\begin{array}{l}\text { Traditional II } \\
\left(5^{\text {th }} \text { of } 5\right. \\
\text { semesters })\end{array}$ & $\begin{array}{l}\text { January } \\
2012\end{array}$ & $\begin{array}{c}\text { Traditional Nursing Program } \\
\text { Graduated July } 2013\end{array}$ & Adult Health III NURS 2115 \\
\hline $\begin{array}{l}\text { Traditional } \\
\text { III ( } 2^{\text {nd }} \text { of } 5 \\
\text { semesters })\end{array}$ & $\begin{array}{l}\text { January } \\
2013\end{array}$ & Traditional Nursing Program & Adult Health I NURS 1111 \\
\hline $\begin{array}{l}\text { Bridge III } \\
\left(3^{\text {rd }} \text { of } 4\right. \\
\text { semesters })\end{array}$ & $\begin{array}{l}\text { October } \\
2012\end{array}$ & Healthcare Professional Bridge & $\begin{array}{l}\text { Nursing Leadership NURS } 2117 \\
\text { Nursing Women, Child NURS } \\
2311\end{array}$ \\
\hline
\end{tabular}

Fourth Quarter Cohorts and Courses

\begin{tabular}{|c|c|c|c|}
\hline Cohort & $\begin{array}{l}\text { Date } \\
\text { Begun }\end{array}$ & Program & $\begin{array}{c}\text { Courses Summer Semester } \\
2013 \text { (May } 21 \text { - July 25) }\end{array}$ \\
\hline $\begin{array}{l}\text { Traditional } \\
\text { III ( } 3^{\text {nd }} \text { of } 5 \\
\text { semesters })\end{array}$ & $\begin{array}{l}\text { January } \\
2013\end{array}$ & Traditional Nursing Program & $\begin{array}{l}\text { Adult Health II NURS } 1112 \\
\text { Psychiatric Nursing NURS } 2113\end{array}$ \\
\hline $\begin{array}{l}\text { Bridge III } \\
\left(4^{\text {rd }} \text { of } 4\right. \\
\text { semesters })\end{array}$ & $\begin{array}{l}\text { October } \\
2012\end{array}$ & Healthcare Professional Bridge & $\begin{array}{l}\text { Adult Health III NURS } 2115 \\
\text { Students will graduate December } \\
2013\end{array}$ \\
\hline
\end{tabular}

\section{Body}

The statement of work items from the official proposal are in bold print before the response for that item.

- Netbook/laptop versions of English 1102, Communication 1101, PSYC 2115 and PHED 1161 will be developed for deployed students with limited or no internet accessibility. Netbook/laptop versions of English 1102, Communication 1101, PSYC, and PHED 1161 for deployed students with limited or no internet accessibility are in various stages of completion. These will be completed during the next cycle.

- Based on the evaluation of the 15 credit hours of nursing courses developed in the first year, modifications and improvements will be made to these courses.

Modifications have been made, and as evaluations are completed, additional modifications were made as indicated by the evaluations. In addition, the University System of Georgia changed course management systems to Desire2Learn. The courses completed so far in the Fort Benning programs had to be converted to the new system beginning with Spring Semester 2013. The courses for each semester were converted prior to the semester they were offered.

- The second cohort of the traditional nursing program graduated Summer Semester 2013. Some of these students have taken boards, and others are still reviewing and preparing for their NCLEX exams. 
- A third cohort of the Healthcare Professional Bridge program will begin October 2012. This cohort started as scheduled.

- A third cohort of the traditional nursing program began January 2013. This cohort began as scheduled.

- Research: Summer 2012, Fall 2012, Spring 2013 and Summer 2013

The qualitative and quantitative evaluations of Fall Semester 2012 were completed in the second quarter report, and Spring Semester 2013 qualitative evaluations were conducted during the third quarter. The evaluations of Summer Quarter 2013 were conducted in the Fall 2013 Semester. Results of this are included later in this document.

- Surveys, evaluations, phone interviews, and focus groups were used to provide formative feedback on courses, resources, mentoring, support services, and the overall program. The results were analyzed and recommendations made and implemented. The results are summarized below, and supporting documents are attached. Modifications and improvements to courses, as described in the Statement of Work, are ongoing each semester. The results of focus group meetings, telephone interviews, and surveys are used to improve the courses and services as needed each semester.

The results were analyzed, and results are included in this report. The individual semester qualitative reports were included in the quarterly reports. The results have been combined for this annual report. This was not difficult since the students seem to have much of the same comments from semester to semester. Overall, the students are extremely pleased with the program and say that without the flexibility of the program, they would not be able enroll in a nursing program because of the rigid nature of these programs.

\section{Focus Groups}

The focus groups meetings were conducted each semester in Columbus in the classroom and lab facilities with the exception of one on the Darton State College main campus. These meetings covered the previous semester's courses.

\begin{tabular}{|l|l|l|}
\hline January 22, 2013 & Traditional Cohort II & $\begin{array}{l}\text { Classroom at 1450 54th Street; } \\
\text { Columbus, GA }\end{array}$ \\
\hline January 23, 2013 & Bridge Cohort III & $\begin{array}{l}\text { On base at Martin Army Hospital } \\
\text { Simulation Lab }\end{array}$ \\
\hline January 24 and 28, 2013 & $\begin{array}{l}\text { Traditional Cohort } \\
\text { III }\end{array}$ & $\begin{array}{l}\text { Classroom at 1450 54th Street; } \\
\text { Columbus, GA }\end{array}$ \\
\hline June 17 & Traditional Cohort II & $\begin{array}{l}\text { Darton State College Nursing } \\
\text { Division Classroom }\end{array}$ \\
\hline August 21, 2013 & Bridge Cohort III & $\begin{array}{l}\text { Classroom at 1450 54th Street; } \\
\text { Columbus, GA }\end{array}$ \\
\hline August 21, 2013 & $\begin{array}{l}\text { Traditional Cohort } \\
\text { III }\end{array}$ & $\begin{array}{l}\text { Classroom at 1450 54th Street; } \\
\text { Columbus, GA }\end{array}$ \\
\hline
\end{tabular}




\section{Annual Summary}

\section{Focus Groups}

The purpose of the focus group meetings is to have a face-to-face meeting with the students to facilitate communication between them and the Grant Department. It has been very helpful in determining improvements that need to be made to the program and in solving problems for students.

The meetings begin with introductions, and various items of business are handled such as having the students sign informed consent forms that tell them what we do with the data we collect. They are assured that the focus group meetings are strictly confidential. They are also encouraged to call the Grants Department for support in whatever the students need, whether it is admissions, financial aid, cashier, etc.

In the focus groups sessions each semester, students were asked their opinions on their obstacles to success, benefits of the program, the benefits of online instruction, and about effective and not so effective components. They have the opportunity to let us know whether they have good communication with their instructors, whether they feel connected to the course, as well as how they thought the program could be improved. They were also asked about any technical difficulties and how they were handled. They also have the opportunity to discuss any academic issues.

The results show that the students continue to have the same obstacles, mainly time management and juggling work schedules and families. They also describe issues with financial aid, fees, out-of- state tuition, etc.; the Grant Department goes to great lengths to solve these problems for them where possible.

The most frequent comment students give about the benefits of the program is flexibility that allows them to work full time, have families, and go to school. Most programs insist that students not work full time and are very inflexible in scheduling. The Fort Benning instructors are very good about scheduling to accommodate these students where possible. The students also like the smaller class size that allows the professor to get to know the students and to understand student strengths and weaknesses.

Another benefit is providing for deployment and temporary duty away at another location. An active duty student indicated that he would be gone for military training from October 15 to November 15 in Texas. He is working with his instructors to make up the clinicals and will have to have access to course and testing materials online while he is gone. Another student who is a dependent stated that her husband was being sent to Okinawa, Japan and that she would accompany him, so she would need support services as well. Note: This student was allowed to do her clinicals before leaving for Okinawa on September 19; she will be able to complete the rest of this semester online. She will return in January 2014 to begin the Spring Semester and repeat the process. She will do the same for the Summer Semester and graduate at the end of July.

The students describe great satisfaction with online 24/7 accessibility, although they also like face-to-face meetings. They like being able to download course and study material to various devices, allowing them to study anywhere anytime. The effective components include lab 
lectures, clinicals, ATI, Evolve, the interactive resources, PowerPoints, and YouTube videos. They especially like the quick availability of their instructors and each other through phone calls, texting, and email. They also had academic questions about having to re-take Anatomy and Physiology if it was over five years old and the Georgia history requirement. Although academic issues are the purview of the Nursing Division, we were able to get the answers to these questions. Technical problems have decreased over time; very few problems were reported, and those were resolved. They like the mentoring program, some stating that it has been essential to their success.

Some continue to express dissatisfaction with student services on the Darton campus in not being able to get phone calls through. Mandatory state budget cuts have continued and made it very difficult to add needed personnel. At the focus group meetings, it continued to be emphasized that they were to call the Grant Office to handle these problems, and many do.

They continue to be very thankful to be a part of the program, stating that this program is the only way they could have worked toward their goal of becoming registered nurses.

(See the Focus Group Meetings Annual Summary Report attachment for further details.)

\section{Telephone Interviews}

The students are telephoned each semester so that they have an opportunity to discuss the previous semester courses and to provide them with the opportunity to let us know what is satisfactory, and what needs improvement. Overall, the students continue to be very pleased with the program. They emphasized the flexibility of the program and the willingness of their instructors to work around their work schedules. They say that their instructors are remarkably available, mainly through texting, with a quick response time. Many of the students still do not like required Discussion Threads in the online system but understand that every course offered by Darton State College must have a Writing Across the Curriculum assignment as a mandatory component, and the Discussion Threads satisfy that requirement. When asked what obstacles they face in the program, the answers remain consistent across the semesters: families, jobs, and, in some cases, a spouse who has been deployed.

Some say that they have no obstacles because the program is so flexible. Fewer students complained about Darton campus personnel not answering the phone and not returning calls, probably because they have finally understood that they can call the Grant Department, and we will handle problems for them. The students are happy with the Grants Department, rating it as 4.9 out of a possible 5 (the best score).

A few students reported being unhappy with the organization of Desire2Learn. This is the online system adopted by the University System of Georgia and is being used by all University Systems schools. Darton technicians have been working to respond to student complaints.

Students were also asked for overall comments about the Customized Nursing program. They are very enthusiastic about the program.

(See the Annual Telephone Interviews Summary Report and the spreadsheet summary for each semester attachments for details.) 


\section{Online Surveys}

Online surveys were also conducted each semester. The results support the outcomes of the focus groups and telephone interviews. Students reported significant satisfaction with their courses and resources. They are happy with the communication with their instructors. We believe that the instructors are trying very hard to meet student needs.

To determine how the program is viewed by students, they were asked a series of questions on how easy the resources were to navigate and use, and whether they would recommend the courses to fellow students. The responses were very favorable. $92.06 \%$ of students found the online site either easy or somewhat easy to navigate with $90.2 \%$ finding the system easy to use or somewhat easy. $90.3 \%$ would likely recommend the courses to fellow students.

In questions designed to determine how well the instructors presented the material, $95.33 \%$ were always or usually pleased with their instructors. $94.97 \%$ would definitely or very likely take another course from the instructor.

$91.57 \%$ thought that the courses were successful in familiarizing them with the nursing field and vocabulary.

Students were asked to rate their online resources on a scale of 0 to 5 with 0 being the least helpful and 5 being the most helpful. If they did not use a particular resource, they could rate it N/A. Only $13.67 \%$ rated the resources 3 or below with the rest rating them 4, 5, or N/A.

(See the spreadsheet attachments for each semester for further details on the results of the online surveys.)

\section{Mentoring Program}

The telephone interviews, the focus groups, and the online surveys reveal that the mentoring program has been very important to many of the Fort Benning students. They are very interested in improving their study and time management skills. This program continues to be conducted by the Fort Benning faculty who, as part of their required duties, schedule study sessions and review sessions both face-to-face and electronically as well meet individually with students. In addition, Ms. Verna Inandan, who is a mentor for Darton nursing students, continues to travel to the Columbus campus to conduct mentoring sessions, continues updates and maintenance of web based mentoring resources for the Fort Benning cohorts, and continues to communicate with the Fort Benning faculty as the need arises.

In her meetings with students she discussed dividing topics using unit objectives to study on a daily basis and to use the two days before the exam for practice questions. She discussed different study techniques in addition to just reading. She also discussed test-taking tips in multiple choice items. She showed them the Nurse Mentor page in the Nursing Support Pages. In addition, she discussed time management and the use of a study calendar with specific goals for each day. She introduced the use of the study graphs as a learning tool to focus on important topics only. She discussed compare-and-contrast and taught how to follow the nursing process. She also reviewed test-taking techniques for multiple choice questions and priority questions. For one cohort, she also did a quick renal review as requested since they were having an exam that afternoon. They were very appreciative of the discussion. 
Ms. Inandan helps to prepare students for the NCLEX-RN exam by discussing the time frame needed for adequate review, the importance of doing many practice questions, and how to prepare for the big exam emotionally. She also gives examples of the reasons why some students were not successful

Key Research Accomplishments

- Group comparison between each of the Fort Benning programs and the respective comparison program. Independent t-tests and Levene's Test for Equality of Variances will be used to assess differences between the Fort Benning programs and the Darton College programs in terms of graduating GPA as well as individual semester GPAs (Hypotheses I through IV). Beyond this, we will use chisquare tests to compare the Fort Benning graduates to the Darton College graduates in regard to passing the NCLEX exam (Hypotheses VIII and IX). In addition retention rates, graduation rates and persistence rates of the Fort Benning cohorts will be compared using chi-square tests to the Darton College cohorts (Hypotheses X, XI, XII, XIII, XIV, and XV). Research is included in this report below.

\title{
Quantitative Data Analysis
}

- $\quad$ Research: September 2012 - September 2013

The first set of analyses looked at group comparison between each of the Fort Benning programs and the respective comparison program. Independent t-tests and Levene's Test for Equality of Variances were used to assess differences between the Fort Benning programs and the Darton College programs in terms of graduating GPA as well as individual semester GPAs (Hypotheses I through IV). Beyond this, we used chi-square tests to compare the Fort Benning graduates to the Darton College graduates in regard to passing the NCLEX exam (Hypotheses VIII and IX). In addition retention rates, graduation rates and persistence rates of the Fort Benning cohorts were compared using chi-square tests to the Darton College cohorts (Hypotheses X, XI, XII, XIII, XIV, and XV).

\author{
Customized Nursing Programs for the Fort Benning Community \\ Report October 2013 \\ Regine Haardörfer, Ph.D.
}

\section{Bridge Cohorts}

1. The first bridge cohort - Graduated Fall 2011The first bridge cohort started with 13 Fort Benning students. The students were almost equally male $(53.8 \%)$ and female $(46.2 \%)$. Of the 12 students who provided race, 7 were African American and 5 where Caucasian. All students but one were part-time students. In the third semester, 2 students left the cohort. The remaining 11 completed all four semesters of the program (Table B1.1)

Overall, a higher percentage of men and African Americans were enrolled in the Fort Benning cohort than in the Albany cohort. The Fort Benning cohort was, on average, about 1.5 years older than the Albany cohort. Both cohorts had equally high percentages of part-time students. (Table B1.1)

Despite these differences, the Fort Benning cohort was not statistically significantly different on key demographics (gender, race, and age) from the Albany cohort. 
Table B1.1. Comparing descriptives of the first Fort Benning Bridge Cohort students with the concurrent Albany cohort in the first semester

\begin{tabular}{|c|c|c|c|c|c|}
\hline & $\mathbf{N}$ & $\%$ & $\mathbf{N}$ & $\%$ & p-value \\
\hline \multicolumn{6}{|l|}{ Gender $(\mathrm{N}=13)$} \\
\hline Female & 6 & $46.2 \%$ & 26 & $63.4 \%$ & \multirow[b]{2}{*}{.270} \\
\hline Male & 7 & $53.8 \%$ & 14 & $34.1 \%$ & \\
\hline \multicolumn{6}{|l|}{ Race $(\mathrm{N}=12)$} \\
\hline Caucasian & 5 & $41.7 \%$ & 26 & $65.0 \%$ & \multirow[b]{3}{*}{.254} \\
\hline African American & 7 & $58.3 \%$ & 13 & $32.5 \%$ & \\
\hline Asian & 0 & - & 1 & $2.5 \%$ & \\
\hline \multicolumn{6}{|c|}{ Full-time/part-time student } \\
\hline Full-time & 1 & $7.7 \%$ & 1 & $2.4 \% \%$ & \multirow[b]{2}{*}{.382} \\
\hline \multirow[t]{2}{*}{ Part-time } & 12 & $92.3 \%$ & 40 & $97.6 \%$ & \\
\hline & Mean & SD & Mean & SD & \\
\hline Age at program start & 38.46 & 7.11 & 36.98 & 8.10 & .556 \\
\hline
\end{tabular}

Table B1.2 shows that the Fort Benning cohort had a slightly higher graduating GPA that was not statistically significantly higher than the graduating GPA of the Albany cohort (Hypothesis II). Furthermore, there was not statistically significantly difference between individual semester GPAs between the cohorts (Hypothesis IV). The means were sometimes higher in the Fort Benning group (semesters 1 and 3) and sometimes higher in the Albany group (semesters 2 and 4). The same was true for the GPA from only the nursing courses.

There was no statistically significant difference in graduation rates from the Fort Benning Bridge cohort with $76.9 \%$ of the students graduating and the Albany cohort (Hypothesis XV). There was also not difference in retention rates with $84.6 \%$ of the students enrolled for at least one year (Hypothesis XIV).

All of the Fort Benning students that graduated from the program passed the NCLEX exam compared to $82.1 \%$ from of the Albany students. The difference was not statistically significant due to the small sample size.

Table B1.2. Comparing the Fort Benning and the Albany cohorts on key success indicators

\begin{tabular}{|c|c|c|c|c|c|}
\hline & \multicolumn{2}{|c|}{ Fort Benning } & \multicolumn{2}{|c|}{ Albany } & \multirow[b]{2}{*}{ p-value } \\
\hline & Mean & SD & Mean & SD & \\
\hline Graduating GPA & 3.228 & 0.332 & 3.166 & 0.382 & .641 \\
\hline \multicolumn{6}{|l|}{ Semester GPAs } \\
\hline 1. Semester & 3.121 & 0.575 & 3.057 & 0.405 & .657 \\
\hline 2. Semester & 2.667 & 0.604 & 2.905 & 0.514 & .172 \\
\hline 3. Semester & 3.000 & 0.636 & 3.061 & 0.452 & .699 \\
\hline 4. Semester & 3.130 & 0.837 & 3.050 & 0.613 & .724 \\
\hline \multicolumn{6}{|c|}{ GPA from Nursing courses per semester } \\
\hline 1. Semester & 3.139 & 0.634 & 2.976 & 0.371 & .394 \\
\hline 2. Semester & 2.585 & 0.518 & 2.858 & 0.541 & .114 \\
\hline 3. Semester & 2.920 & 0.594 & 3.000 & 0.501 & .661 \\
\hline 4. Semester & 3.091 & 0.831 & 3.077 & 0.580 & .949 \\
\hline Retention rates & $\mathbf{N}$ & $\%$ & $\mathbf{N}$ & $\%$ & \\
\hline At least one year & 11 & $84.6 \%$ & 39 & $95.1 \%$ & \multirow[b]{2}{*}{.208} \\
\hline Less than one year & 2 & $15.4 \%$ & 2 & $4.9 \%$ & \\
\hline \multicolumn{6}{|l|}{ Graduation rates } \\
\hline Yes & 10 & $76.9 \%$ & 38 & $92.7 \%$ & \multirow[b]{2}{*}{.115} \\
\hline No & 3 & $23.1 \%$ & 3 & $7.3 \%$ & \\
\hline \multicolumn{6}{|c|}{ NCLEX Exam rates - first attempt } \\
\hline Yes & 7 & $70.0 \%$ & 32 & $82.1 \%$ & \multirow[b]{2}{*}{.399} \\
\hline No & 3 & $30.0 \%$ & 7 & $17.9 \%$ & \\
\hline
\end{tabular}




\section{B2. The second Bridge Cohort - graduated Fall 2012}

The second bridge cohort started in the fall of 2011 with 12 students. The large majority was female $(75 \%)$ and African American (75\%). Most students were enrolled part time $(83.3 \%)$ and the average age was almost 38 years (Table B2.1).

The racial composition of the Fort Benning cohort is statistically significantly different than that of the Albany cohort (Table B2.1) with a higher percentage of African Americans. The two cohorts are not significantly different in terms of gender, age, and part-time/full-time student status.

Table B2.1. Comparing descriptives of the first Fort Benning Bridge Cohort students with the concurrent Albany cohort in the first semester

\begin{tabular}{|c|c|c|c|c|c|}
\hline & \multicolumn{2}{|c|}{ Fort Benning } & \multicolumn{2}{|c|}{ Albany } & \multirow[b]{2}{*}{ p-value } \\
\hline & $\mathbf{N}$ & $\%$ & $\mathbf{N}$ & $\%$ & \\
\hline \multicolumn{6}{|l|}{ Gender } \\
\hline Female & 9 & $75.0 \%$ & 35 & $71.4 \%$ & \multirow[b]{2}{*}{.805} \\
\hline Male & 3 & $25.0 \%$ & 14 & $28.6 \%$ & \\
\hline \multicolumn{6}{|l|}{ Race } \\
\hline Caucasian & 3 & $25.0 \%$ & 30 & $68.2 \%$ & \multirow[b]{2}{*}{$.007 * *$} \\
\hline African American & 9 & $75.0 \%$ & 14 & $31.8 \%$ & \\
\hline \multicolumn{6}{|c|}{ Full-time/part-time student } \\
\hline Full-time & 2 & $16.7 \%$ & 7 & $14.3 \%$ & \multirow{3}{*}{.835} \\
\hline \multirow[t]{2}{*}{ Part-time } & 10 & $83.3 \%$ & 42 & $85.7 \%$ & \\
\hline & Mean & SD & Mean & SD & \\
\hline Age at program start & 37.83 & 6.90 & 36.59 & 8.57 & .643 \\
\hline
\end{tabular}

Note: $* * p<.01$.

Table B2.2 shows the mean semester GPAs for both cohorts as well as the GPA from the nursing courses for all semesters as well as the graduating GPA. The graduating GPA of the Fort Benning cohort was higher (3.297) than that of the Albany cohort (3.112). However, the difference was not statistically significant. In the first semester, the Fort Benning students performed statistically significantly better than the Albany students both in their nursing courses as well as overall. Their average first semester GPA was higher by 0.386 and their average GPA from the nursing courses was higher by more than 0.5 . Those differences in semester GPA (which was identical to the GPA from nursing courses) were not observed in the second, third, and fourth semester. However, the GPA in the $4^{\text {th }}$ semester was higher by more than 0.3 for the Fort Benning students.

Retention rates and graduation rates were comparable between the cohorts and about $80 \%$. 
Table B2.2. Comparing the Fort Benning and the Albany cohorts on key success indicators

\begin{tabular}{|c|c|c|c|c|c|}
\hline & \multicolumn{2}{|c|}{ Fort Benning } & \multicolumn{2}{|c|}{ Albany } & \multirow[b]{2}{*}{ p-value } \\
\hline & Mean & SD & Mean & SD & \\
\hline Graduating GPA & 3.297 & 0.357 & 3.112 & 0.393 & .20 \\
\hline \multicolumn{6}{|l|}{ Semester GPAs } \\
\hline 1. Semester & 3.451 & 0.406 & 3.065 & 0.511 & $.018 *$ \\
\hline 2. Semester & 2.682 & 0.760 & 2.786 & 0.551 & .652 \\
\hline 3. Semester & 3.130 & 0.489 & 2.856 & 0.601 & .153 \\
\hline 4. Semester & 3.297 & 0.640 & 2.963 & 0.451 & .05 \\
\hline \multicolumn{6}{|c|}{ GPA from Nursing courses per semester } \\
\hline 1. Semester & 3.467 & 0.365 & 2.959 & 0.658 & $.013 *$ \\
\hline 2. Semester & 2.682 & 0.760 & 2.786 & 0.551 & .652 \\
\hline 3. Semester & 3.130 & 0.489 & 2.856 & 0.601 & .153 \\
\hline 4. Semester & 3.091 & 0.701 & 2.952 & 0.491 & .451 \\
\hline Retention rates & $\mathbf{N}$ & $\%$ & $\mathbf{N}$ & $\%$ & \\
\hline At least one year & 10 & $76.9 \%$ & 40 & $81.6 \%$ & \\
\hline Less than one year & 3 & $23.1 \%$ & 9 & $18.4 \%$ & .70 \\
\hline \multicolumn{6}{|l|}{ Graduation rates } \\
\hline Yes & 10 & $76.9 \%$ & 39 & $76.5 \%$ & .96 \\
\hline
\end{tabular}

Note: $* p<.05$.

\section{B3. Third Bridge Cohort - Started Fall 2012}

The third bridge cohort started in the fall of 2012 with 10 Fort Benning students. The large majority was female (70\%) and African American (80\%). Most students were enrolled part time $(80.0 \%)$ and the average age was just above 38 years (Table B3.1).

The racial composition of the Fort Benning cohort is statistically significantly different than that of the Albany cohort (Table B3.1) with a higher percentage of African Americans. The two cohorts are not significantly different in terms of gender, age, and part-time/full-time student status.

Table B3.1. Comparing descriptives of the first Fort Benning Bridge Cohort students with the concurrent Albany cohort in the first semester

\begin{tabular}{|c|c|c|c|c|c|}
\hline & \multicolumn{2}{|c|}{ Fort Benning } & \multicolumn{2}{|c|}{ Albany } & \multirow[b]{2}{*}{ p-value } \\
\hline & $\mathbf{N}$ & $\%$ & $\mathbf{N}$ & $\%$ & \\
\hline \multicolumn{6}{|l|}{ Gender } \\
\hline Female & 7 & $70.0 \%$ & 48 & $82.8 \%$ & \multirow[b]{2}{*}{.343} \\
\hline Male & 3 & $30.0 \%$ & 10 & $17.2 \%$ & \\
\hline \multicolumn{6}{|l|}{ Race } \\
\hline Caucasian & 2 & $20.0 \%$ & 33 & $60.0 \%$ & \multirow[b]{3}{*}{$.049 *$} \\
\hline African American & 8 & $80.0 \%$ & 21 & $38.2 \%$ & \\
\hline Asian & 0 & - & 1 & $1.8 \%$ & \\
\hline \multicolumn{6}{|c|}{ Full-time/part-time student } \\
\hline Full-time & 2 & $20.0 \%$ & 4 & $6.9 \%$ & \multirow[b]{2}{*}{.177} \\
\hline \multirow[t]{2}{*}{ Part-time } & 8 & $80.0 \%$ & 54 & $93.1 \%$ & \\
\hline & Mean & SD & Mean & SD & \\
\hline Age at program start & 38.10 & 7.52 & 34.07 & 6.65 & .087 \\
\hline
\end{tabular}

Note: $* p<.05$.

Table B3.2 shows the mean semester GPAs for both cohorts as well as the GPA from the nursing courses of the first semester. In both cases, the Fort Benning students performed better than the Albany students. Their average first semester GPA was significantly higher by 0.321 
and their average GPA from the nursing courses was higher by 0.209 (not significant).

However, in the second and third semesters the GPA of both groups were very similar (around 2.3 in the second and around 2.7 in the third) both for the nursing courses GPA and the overall GPA.

Table B3.2. Comparing the Fort Benning and the Albany cohorts on key success indicators

\begin{tabular}{|c|c|c|c|c|c|}
\hline & \multicolumn{2}{|c|}{ Fort Benning } & \multicolumn{2}{c|}{ Albany } & \\
\hline & Mean & SD & Mean & SD & p-value \\
\hline Semester GPAs & & & & & \\
\hline 1. Semester & 2.900 & 0.216 & 2.579 & 0.769 & $.01^{*}$ \\
\hline 2. Semester & 2.376 & 0.591 & 2.277 & 0.960 & .75 \\
\hline 3. Semester & 2.706 & 0.491 & 2.742 & 0.627 & .85 \\
\hline GPA from Nursing courses per semester & & & & & \\
\hline 1. Semester & 2.972 & 0.328 & 2.763 & 0.657 & .33 \\
\hline 2. Semester & 2.349 & 0.618 & 2.324 & 0.983 & .94 \\
\hline 3. Semester & 2.666 & 0.468 & 2.737 & 0.474 & .68 \\
\hline
\end{tabular}

Note: $* p<.05$.

Traditional Cohorts

T1. First Traditional Cohort - Started Spring 2011, graduated Summer 2012

The first traditional Fort Benning cohort started with 13 students. Most were female (84.6\%) and African American (50\%). All were enrolled as part-time students. The average age was almost 38 years.

The Fort Benning cohort had more men and more African Americans enrolled than the Albany cohort. The Fort Benning students were, on average, about 3 years older. However, the differences were not statistically significant (Table T1.1).

Table T1.1. Comparing descriptives of the first Fort Benning traditional hybrid Cohort students with the concurrent Albany traditional hybrid cohort in the first semester

\begin{tabular}{|c|c|c|c|c|c|}
\hline & \multicolumn{2}{|c|}{ Fort Benning } & \multicolumn{2}{|c|}{ Albany } & \multirow[b]{2}{*}{ p-value } \\
\hline & $\mathbf{N}$ & $\%$ & $\mathbf{N}$ & $\%$ & \\
\hline \multicolumn{6}{|l|}{ Gender } \\
\hline Female & 11 & $84.6 \%$ & 28 & $90.3 \%$ & \multirow[b]{2}{*}{.586} \\
\hline Male & 2 & $15.4 \%$ & 3 & $9.7 \%$ & \\
\hline \multicolumn{6}{|l|}{ Race } \\
\hline Caucasian & 5 & $41.7 \%$ & 20 & $69.0 \%$ & \multirow[b]{3}{*}{.117} \\
\hline African American & 6 & $50.0 \%$ & 9 & $31.0 \%$ & \\
\hline American-Indian or Alaskan Native & 1 & $8.3 \%$ & 0 & - & \\
\hline \multicolumn{6}{|l|}{ Full-time/part-time student } \\
\hline Full-time & 0 & - & 1 & $3.2 \%$ & \multirow[b]{2}{*}{.512} \\
\hline \multirow[t]{2}{*}{ Part-time } & 13 & $100 \%$ & 30 & $96.8 \%$ & \\
\hline & Mean & SD & Mean & SD & \\
\hline Age at program start & 37.85 & 6.45 & 34.58 & 9.17 & .189 \\
\hline
\end{tabular}

Table T1.2 shows the mean semester GPAs and the mean GPAs per semester from the nursing courses. There were no statistically significant differences in the semester GPAs between the Fort Benning and the Albany students. The means were higher for the Fort Benning students in the first semester and lower in the subsequent semesters. The mean nursing GPAs show similar patterns. However, the Albany students had a significantly higher GPA in their nursing courses during the second semester.

More students in the Fort Benning cohort (84.6\%) were retained for at least 4 semesters than in the Albany cohort (72.7\%), although the difference was not statistically significant (Table T1.2). 
Table T1.2. Comparing the traditional Fort Benning and the Albany cohorts on key success indicators

\begin{tabular}{|c|c|c|c|c|c|}
\hline & \multicolumn{2}{|c|}{ Fort Benning } & \multicolumn{2}{|c|}{ Albany } & \multirow[b]{2}{*}{ p-value } \\
\hline & Mean & SD & Mean & SD & \\
\hline Graduating GPA & 2.950 & 0.322 & 2.899 & 0.438 & .743 \\
\hline \multicolumn{6}{|l|}{ Semester GPAs } \\
\hline 1. Semester & 2.935 & 0.629 & 2.893 & 0.472 & .809 \\
\hline 2. Semester & 2.519 & 0.632 & 2.859 & 0.364 & .091 \\
\hline 3. Semester & 2.708 & 0.889 & 2.924 & 0.379 & .417 \\
\hline 4. Semester & 2.427 & 0.516 & 2.587 & 0.500 & .413 \\
\hline 5. Semester & 2.818 & 0.751 & 2.826 & 0.388 & .564 \\
\hline \multicolumn{6}{|c|}{ GPA from Nursing courses per semester } \\
\hline 1. Semester & 2.910 & 0.618 & 2.838 & 0.617 & .725 \\
\hline 2. Semester & 2.462 & 0.660 & 2.885 & 0.326 & $.045^{*}$ \\
\hline 3. Semester & 2.723 & 0.860 & 2.915 & 0.390 & .456 \\
\hline 4. Semester & 2.427 & 0.516 & 2.587 & 0.500 & .413 \\
\hline 5. Semester & 2.818 & 0.751 & 2.826 & 0.388 & .564 \\
\hline Retention rates & $\mathbf{N}$ & $\%$ & $\mathbf{N}$ & $\%$ & \\
\hline More than one year & 11 & 84.6 & 25 & 80.6 & \multirow[b]{2}{*}{.395} \\
\hline Less than one year & 2 & 15.4 & 6 & 19.4 & \\
\hline \multicolumn{6}{|l|}{ Graduation rates } \\
\hline Yes & 8 & 61.5 & 20 & 64.5 & .94 \\
\hline
\end{tabular}

\section{T2.Second Traditional Cohort - Started Spring 2012, graduated Summer 2013}

The second traditional hybrid cohort started in the spring of 2012 with 14 students. Please note: With no parallel Albany cohort in spring 2012, this cohort will be compared the Albany hybrid cohort that started in spring of 2011. All but one of the students are female (93\%) and Caucasian (71.4\%). All students were enrolled part time and the average age was almost 38 years (Table T2.1).

The two cohorts are not significantly different in regard to demographic composition.

Table T2.1. Comparing descriptives of the second traditional Fort Benning Bridge Cohort students with the first traditional Albany cohort

\begin{tabular}{|c|c|c|c|c|c|}
\hline & \multicolumn{2}{|c|}{ Fort Benning } & \multicolumn{2}{|c|}{ Albany } & \multirow[b]{2}{*}{ p-value } \\
\hline & $\mathbf{N}$ & $\%$ & $\mathbf{N}$ & $\%$ & \\
\hline \multicolumn{6}{|l|}{ Gender } \\
\hline Female & 13 & $92.9 \%$ & 28 & $90.3 \%$ & \multirow[b]{2}{*}{.63} \\
\hline Male & 1 & $7.1 \%$ & 3 & $9.7 \%$ & \\
\hline \multicolumn{6}{|l|}{ Race } \\
\hline Caucasian & 10 & $71.4 \%$ & 20 & $69.0 \%$ & \multirow[b]{2}{*}{.58} \\
\hline African American & 4 & $28.6 \%$ & 9 & $31.0 \%$ & \\
\hline \multicolumn{6}{|c|}{ Full-time/part-time student } \\
\hline Full-time & 0 & $0 \%$ & 1 & $3.2 \%$ & \multirow[b]{2}{*}{.69} \\
\hline \multirow[t]{2}{*}{ Part-time } & 14 & $100 \%$ & 30 & $96.8 \%$ & \\
\hline & Mean & SD & Mean & SD & \\
\hline Age at program start & 30.57 & 4.64 & 34.58 & 9.17 & .58 \\
\hline
\end{tabular}

Table T2.2 shows the mean semester GPAs for both cohorts as well as the GPA from the nursing courses of the four semesters. In both cases, the Fort Benning students did as well as the Albany students during the first four semesters. However, in the $5^{\text {th }}$ semester, the Fort Benning students had significantly higher nursing courses GPAs well as their overall GPAs. 
The average Fort Benning students' graduating GPA's were slightly higher than the Albany students'. Retention rates were comparable for the two groups.

Table T2.2. Comparing the second traditional Fort Benning cohort and the first Albany traditional cohort on key success indicators

\begin{tabular}{|l|c|c|c|c|c|}
\hline & \multicolumn{2}{|c|}{ Fort Benning } & \multicolumn{2}{c|}{ Albany } & \\
\hline & Mean & SD & Mean & SD & p-value \\
\hline Graduating GPA & 3.117 & 0.288 & 2.950 & 0.323 & .18 \\
\hline Semester GPAs & & & & & \\
\hline 1. Semester & 2.752 & 0.699 & 2.894 & 0.472 & .43 \\
\hline 2. Semester & 2.818 & 0.751 & 2.696 & 0.470 & .56 \\
\hline 3. Semester & 2.722 & 0.962 & 2.924 & 0.379 & .38 \\
\hline 4. Semester & 2.445 & 1.560 & 2.587 & 0.500 & .67 \\
\hline 5. Semester & 3.333 & 0.431 & 2.696 & 0.470 & $<.001^{* *}$ \\
\hline GPA from Nursing courses per semester & & & & & \\
\hline 1. Semester & 2.752 & 0.699 & 2.838 & 0.617 & .68 \\
\hline 2. Semester & 2.818 & 0.751 & 2.696 & 0.470 & .56 \\
\hline 3. Semester & 2.873 & 1.278 & 2.915 & 0.390 & .88 \\
\hline 4. Semester & 2.444 & 1.568 & 2.587 & 0.500 & .67 \\
\hline 5. Semester & 3.333 & 0.431 & 2.696 & 0.470 & $.001^{* *}$ \\
\hline Retention rates & $\mathbf{N}$ & $\mathbf{\%}$ & $\mathbf{N}$ & $\mathbf{\%}$ & \\
\hline More than one year & 10 & 71.4 & 25 & 80.6 & \multirow{2}{*}{} \\
\hline Less than one year & 4 & 28.6 & 6 & 19.4 & .16 \\
\hline Graduation rates & & & & & \\
\hline Yes & 9 & 64.3 & 20 & 64.5 & .89 \\
\hline
\end{tabular}

Note: $* * p<.01 . * * * \mathrm{p}<.001$.

\section{T3. Third Traditional Cohort - Started in Spring 2013}

The third traditional cohort started in the spring of 2013 with 12 students. All but two of the students are female $(83.3 \%)$ and half are Caucasian (50.0\%). All students but one were enrolled part time $(91.7 \%)$ and the average age was around 31 years (Table T3.1). The two cohorts are not significantly different in regard to demographic composition. However, the age of the students in the Fort Benning group is less diverse than the Albany group; i.e. the Fort Benning group has a much smaller standard deviation for age than the Albany group.

Table T3.1. Comparing descriptives of the second traditional Fort Benning Cohort students with the traditional hybrid Albany Spring 2013 cohort

\begin{tabular}{|c|c|c|c|c|c|}
\hline & \multicolumn{2}{|c|}{ Fort Benning } & \multicolumn{2}{|c|}{ Albany } & \multirow[b]{2}{*}{ p-value } \\
\hline & $\mathbf{N}$ & $\%$ & $\mathbf{N}$ & $\%$ & \\
\hline \multicolumn{6}{|l|}{ Gender } \\
\hline Female & 10 & 83.3 & 21 & 77.8 & \multirow[b]{2}{*}{.32} \\
\hline Male & 2 & 16.7 & 6 & 22.2 & \\
\hline \multicolumn{6}{|l|}{ Race } \\
\hline Caucasian & 6 & 50.0 & 16 & 59.3 & \multirow[b]{3}{*}{.78} \\
\hline African American & 5 & 41.7 & 9 & 33.3 & \\
\hline Other race & 1 & 8.3 & 2 & 7.4 & \\
\hline \multicolumn{6}{|c|}{ Full-time/part-time student } \\
\hline Full-time & 1 & 8.3 & 4 & 14.8 & \multirow{3}{*}{.58} \\
\hline \multirow[t]{2}{*}{ Part-time } & 11 & 91.7 & 23 & 85.2 & \\
\hline & Mean & SD & Mean & SD & \\
\hline Age at program start & 31.3 & 3.94 & 32.5 & 10.4 & .71 \\
\hline
\end{tabular}

Note: $* * p<.01$. 
Table T3.2 shows the mean semester GPAs for both cohorts as well as the GPA from the nursing courses of the first semester. In both cases, the Fort Benning students had higher average GPAs than the Albany students. The differences, however, were not statistically significant. In the second semester, the Fort Benning students' GPAs were higher by about 0.5 both for the nursing courses and overall. The difference was not statistically significant, due to the small size of the Fort Benning class and the relatively large standard deviations. However, it should be noted that by the second semester, all Fort Benning students were still enrolled, while 10 out of the original 27 students in the Albany cohort had left the program.

Table T3.2. Comparing the second traditional Fort Benning cohort and the first Albany traditional cohort on key success indicators

\begin{tabular}{|c|c|c|c|c|c|}
\hline & \multicolumn{2}{|c|}{ Fort Benning } & \multicolumn{2}{c|}{ Albany } & \\
\hline & Mean & SD & Mean & SD & p-value \\
\hline Semester GPAs & & & & & \\
\hline 1. Semester & 2.723 & 0.510 & 2.303 & 1.025 & .19 \\
\hline 2. Semester & 2.708 & 0.467 & 2.244 & 0.792 & .08 \\
\hline GPA from Nursing courses per semester & & & & & \\
\hline 1. Semester & 2.756 & 0.564 & 2.365 & 1.057 & .24 \\
\hline 2. Semester & 2.667 & 0.492 & 2.188 & 0.834 & .09 \\
\hline
\end{tabular}

Note: $* p<.05$.

\section{Group Differences}

I. Comparison of graduating GPAs of Traditional FB students and Traditional DC students Null Hypothesis: Mean DC $=$ Mean FB

Alternative Hypothesis: Mean DC < Mean FB

Graduating GPA of the Traditional Fort Benning Fall 2010 cohort was slightly higher (Mean $=2.950)$ than of the DC cohort (Mean = 2.899). The difference was not statistically significant, $p>.05$.

For the second cohort, the graduating GPA was higher by 0.167 points on average for the Fort Benning students (Mean = 3.117) than the DC cohort (Mean = 2.950), but not significantly so due to the small number of students in the cohort $(N=14)$.

II. Comparison of graduating GPAs of Accelerated FB students and Accelerated DC students. Null Hypothesis: Mean DC $=$ Mean FB

Alternative Hypothesis: Mean DC $<$ Mean FB

Graduating GPA of the Bridge Fort Benning Fall 2010 cohort was slightly higher (Mean = 3.228) than of the DC cohort (Mean =3.166). The difference was not statistically significant, $p$ $>.05$.

For the second Accelerated cohort, the mean graduating GPA was higher by 0.185 points for the Fort Benning students (Mean =3.297), but not significantly so due to the small number of students.

III. Comparison of each of the individual semester GPAs of Traditional FB students and Traditional DC students.

Null Hypothesis: Mean DC $=$ Mean FB

Alternative Hypothesis: Mean DC $<$ Mean FB 
1. Traditional cohort: Semester GPAs for the Fort Benning students were at times slightly higher and at times slightly lower than those of DC students. None of the differences were large enough to be statistically significant.

2. Traditional cohort: Semester GPAs for the Fort Benning students were at times slightly higher and at times slightly lower than those of DC students during the first four semesters. None of the differences were large enough to be statistically significant. However, the Fort Benning students (Mean $=3.333)$ had on average a significantly higher average semester GPA (difference $=0.637)$ compared to the DC students $($ Mean $=2.696)$ in the fifth and final semester.

IV. Comparison of each of the individual semester GPAs of Accelerated FB students and Accelerated DC students.

Null Hypothesis: Mean DC $=$ Mean FB

Alternative Hypothesis: Mean DC $<$ Mean FB

1. Hybrid cohort: Semester GPAs for the Fort Benning students were at times slightly higher and at times slightly lower than those of DC students. None of the differences were large enough to be statistically significant.

2. Hybrid cohort: In the first semester, the GPAs for the Fort Benning students were significantly higher $(p=.0180$ than those of the DC students. In subsequent semesters, semester GPAs of the Fort Benning students were once slightly lower and once slightly higher than those of DC students, but those differences were not large enough to be statistically significant.

3. Hybrid cohort: Semester GPAs were significantly higher for the Fort Benning students in the first semester ( $p=.01$ ), still higher (but not significantly) during the second semester, and almost identical during the third semester.

V. Comparison of the GPAs of students taking advantage of mentoring (Group M) to students not taking advantage of mentoring (Group NM) in the Traditional FB program.

Null Hypothesis: Mean NM = Mean M

Alternative Hypothesis: Mean NM < Mean M

All students in the Traditional Fort Benning program took advantage of the mentoring. Hence, no differences can be observed.

VI. Comparison of the GPAs of students taking advantage of the mentoring (Group M) to students not taking advantage of the mentoring (Group NM) in the Accelerated FB program. Null Hypothesis: Mean NM = Mean M

Alternative Hypothesis: Mean NM < Mean M

All students in the Accelerated Fort Benning program took advantage of the mentoring. Hence, no differences can be observed.

VII. The Accelerated DC program has been specifically designed for and taught to LPNs and Paramedics. For the Accelerated FB program, Darton College sought and received special approval from the GBON and the NLNAC to include the Army Medic 68W M6. An independent t-test will be employed to determine the relationship between the LPNs and Paramedics group (LPN\&P) and the Army Medic 68W M6 group (AM) in terms of their individual semester GPAs.

Null Hypothesis: Mean LPN\&P = Mean AM

Alternative Hypothesis: Mean LPN\&P $\neq$ Mean AM 
No Army Medic 68W M6 has entered the program so far.

VIII. Comparison of the percentage of graduates passing the NCLEX exam from the Traditional FB program and the Traditional DC program.

Null Hypothesis: Percentage Passing DC = Percentage Passing FB14

Alternative Hypothesis: Percentage Passing DC $<$ Percentage Passing FB

Of the students who graduated from the Traditional FB program in the cohort of Fall 2010, $70 \%$ passed the NCLEX exam on the first attempt compared to $82.1 \%$ of DC students. The remaining $30 \%$ passed on the second attempt. Due to the small cohort size, the difference is not statistically significant.

IX. Comparison of the percentage of graduates passing the NCLEX exam from the Accelerated FB program and the Accelerated DC program

Null Hypothesis: Percentage Passing DC $=$ Percentage Passing FB

Alternative Hypothesis: Percentage Passing DC $<$ Percentage Passing FB

The first Accelerated FB students graduated in Fall 2011. Of this cohort, 60\% passed their NCLEX exam. Of the Fall 2012 cohort, 75\% passed their NCLEX exm; however, more than $50 \%$ of the results are still outstanding, making comparisons not meaningful at this point in time.

X. Comparison of the persistence rates from the Traditional FB program and the Traditional DC program.

Null Hypothesis: Percentage Persisting DC $=$ Percentage Persisting FB

Alternative Hypothesis: Percentage Persisting DC $<$ Percentage Persisting FB

For the first traditional hybrid cohort, the persistence rate for Fort Benning students was $61.5 \%$ and not significantly different from the persistence rate of the Albany students (64.5\%). For the second cohort, the persistence rate for the Fort Benning students was $64.3 \%$ and again not significantly different from the persistence rate of the Albany students (64.5\%). Note, the second Fort Benning cohort was compared to the 2011 traditional hybrid Albany cohort as there was no second Albany cohort available for comparison.

XI. Comparison of the persistence rates from the Accelerated FB program and the Accelerated DC program.

Null Hypothesis: Percentage Persisting DC $=$ Percentage Persisting FB

Alternative Hypothesis: Percentage Persisting DC < Percentage Persisting FB

For the first cohort the Fort Benning students' persistence rates were lower at $76.9 \%$ (with 3 not graduating within $150 \%$ of the allotted time) compared to $92.7 \%$ for the Albany students, but the difference was not statistically significant.

For the second cohort, there was almost no difference, with a persistence rate of $76.9 \%$ for the Fort Benning students and a slight lower persistence rate of $76.5 \%$ for the Albany students. This difference was also not statistically significant due to the small difference.

XII. Comparison of the retention rates from the Traditional FB program and the Traditional DC program.

Null Hypothesis: Percentage Retained DC = Percentage Retained FB

Alternative Hypothesis: Percentage Retained DC $<$ Percentage Retained FB 
The retention rate in the first Traditional FB cohort was higher (84.6\%) than in the Traditional DC cohort (72.7\%). The difference was not statistically significant due to small cohort size.

XIII. Comparison of the retention rates from the Accelerated FB program and the Accelerated DC program

Null Hypothesis: Percentage Retained DC $=$ Percentage Retained FB

Alternative Hypothesis: Percentage Retained DC $<$ Percentage Retained FB

The retention rate in the first Accelerated $F B$ cohort were lower (84.6\%) than in the Accelerated DC cohort (95.1\%) but the difference was not statistically significant.

XIV. Comparison of the graduation rates from the Traditional FB program and the Traditional DC program.

Null Hypothesis: Percentage Graduated DC $=$ Percentage Graduated FB

Alternative Hypothesis: Percentage Graduated DC < Percentage Graduated FB

The graduation rate in the first Traditional FB cohort was higher (84.6\%) than in the Traditional DC cohort (72.7\%). The difference was not statistically significant due to small cohort size

$\mathrm{XV}$. Comparison of the graduation rates from the Accelerated FB program and the Accelerated DC program

Null Hypothesis: Percentage Graduated DC = Percentage Graduated FB

Alternative Hypothesis: Percentage Graduated DC $<$ Percentage Graduated FB

The graduation rate for the first accelerated Fort Benning cohort was $76.9 \%$ and not statistically different from the traditional cohort (92.7\%). In the second cohort, the graduation rates were much more similar with $76.9 \%$ of the FB students graduating compared to $76.5 \%$ of the Albany students graduating.

\section{Reportable Outcomes}

The Customized Nursing programs have resulted in the participants who graduated earning the Associate Degree in Nursing from either the Traditional Hybrid Nursing program or from the Accelerated Bridge program for LPNs, Paramedics and Army Medics 68W M6.

\section{Conclusion}

The Customized Nursing Programs are going well. The students as a whole are very pleased and appreciate the opportunity to be enrolled in a flexible program. Most say without the customization they would not be able to complete a nursing program. The formative evaluations have served the program well and provide opportunities for continual improvement of the program and courses. The courses and resources are of high quality and very effective. The statistical analysis rarely shows any statistical differences from the Fort Benning cohorts and the established Darton College cohorts. The students are doing at least as well as the Darton students on the main campus. The grant department serves as the single point of contact for student for all non-academic issues and the students prefer to deal with us and find us more responsive that the other departments on campus. There are no major problems, and we do not we see any need to make major modifications at the time. 


\begin{tabular}{|c|c|c|c|c|c|c|c|}
\hline \multicolumn{8}{|c|}{ Fall 2012 Semester -Adult Health II NURS 1112 - Traditional II } \\
\hline & Very Easy & Somewhat Easy & Somewhat & Very & & & \\
\hline \multirow{3}{*}{ Was the course easy to navigate? } & $70.0 \%$ & $10.0 \%$ & $\frac{\text { Difficult }}{20.0 \%}$ & \begin{tabular}{rl|} 
Difficult & $0.0 \%$ \\
\end{tabular} & & & \\
\hline & & & Somewhat & & Very & & \\
\hline & $\begin{aligned} & \text { Definitely } \text { 100.0\% } \\
&\end{aligned}$ & $\begin{aligned} \text { Very Likely } \\
0.0 \%\end{aligned}$ & \begin{tabular}{l|}
\multicolumn{2}{l}{ Likely } \\
$0.0 \%$
\end{tabular} & \begin{tabular}{r|r} 
Unilikely $^{\prime}$ \\
$0.0 \%$
\end{tabular} & $\begin{array}{l}\text { unlikely } \\
0.0 \%\end{array}$ & & \\
\hline Would you recommend this course to a fellow student? & & & & & & & \\
\hline Was the online system easy to use? & Always & Often & Occasionally & Rarely & Never & N/A & \\
\hline $\begin{array}{l}\text { Was the written material in the course modules thorough? } \\
\text { What }\end{array}$ & $40.0 \%$ & $50.0 \%$ & $10.0 \%$ & & $0.0 \%$ & & \\
\hline \multirow{2}{*}{$\begin{array}{l}\text { Was the module content clear, organized and easy to follow? } \\
\text { Were the directions for the assignments detailed enough to allow you } \\
\text { to complete the work successfully? }\end{array}$} & $33.3 \%$ & $55.6 \%$ & $11.1 \%$ & $0.0 \%$ & $0.0 \%$ & & \\
\hline & $60.0 \%$ & $40.0 \%$ & $0.0 \%$ & $0.0 \%$ & $0.0 \%$ & & \\
\hline $\begin{array}{l}\text { to complete the work successtuly? } \\
\text { The online system as a whole was easy to use. }\end{array}$ & $40.0 \%$ & $40.0 \%$ & $20.0 \%$ & $0.0 \%$ & $0.0 \%$ & & \\
\hline \multirow{2}{*}{$\begin{array}{l}\text { The email system was sufficient for communications. } \\
\text { The online Help Desk provided timely and satisfactory technical }\end{array}$} & $70.0 \%$ & $30.0 \%$ & $0.0 \%$ & $0.0 \%$ & $0.0 \%$ & & \\
\hline & $40.0 \%$ & $20.0 \%$ & $0.0 \%$ & $0.0 \%$ & $0.0 \%$ & $40.0 \%$ & \\
\hline Average: & $47.2 \%$ & $39.3 \%$ & $6.9 \%$ & $0.0 \%$ & $0.0 \%$ & & \\
\hline & & & & & & & \\
\hline \multirow{3}{*}{$\begin{array}{l}\text { Did the instructors respond and present material well? } \\
\text { When problems or questions arose, did your instructor respond in a } \\
\text { imely fashion? }\end{array}$} & Always & Usually & Sometimes & Never & & & \\
\hline & $90.0 \%$ & $10.0 \%$ & $0.0 \%$ & $0.0 \%$ & $100.0 \%$ & & \\
\hline & $90.0 \%$ & $10.0 \%$ & $0.0 \%$ & $0.0 \%$ & $100.0 \%$ & & \\
\hline \multirow{3}{*}{$\begin{array}{l}\text { Did your instructor clearly explain student expectations? } \\
\text { Did your instructor show enthusiasm for the subject matter? } \\
\text { Were you satisfied with how your instructor presented the material? }\end{array}$} & $90.0 \%$ & $10.0 \%$ & $0.0 \%$ & $0.0 \%$ & $100.0 \%$ & & \\
\hline & $87.5 \%$ & $12.5 \%$ & $0.0 \%$ & $0.0 \%$ & $100.0 \%$ & & \\
\hline & $89.4 \%$ & $10.6 \%$ & $0.0 \%$ & $0.0 \%$ & $100.0 \%$ & & \\
\hline 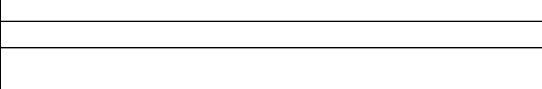 & Definitely & Very Likely & Somewhat & Unlikely & Very & & \\
\hline \multirow{3}{*}{ Would you take another course from your instructor? } & $90.0 \%$ & $10.0 \%$ & \begin{tabular}{r|}
\multicolumn{1}{c|}{ Likely } \\
$0.0 \%$
\end{tabular} & $\begin{aligned} \text { Uimikely } \\
0.0 \%\end{aligned}$ & $\begin{array}{l}\text { unlikely } \\
0.0 \%\end{array}$ & & \\
\hline & & & & & & & \\
\hline & Excellent & Good & Average & Poor & & & \\
\hline $\begin{array}{l}\text { How successful was this class overall in familiarizing you with the } \\
\text { nursing field and vocabulary? }\end{array}$ & $80.0 \%$ & $20.0 \%$ & $0.0 \%$ & $0.0 \%$ & & & \\
\hline \multirow{4}{*}{$\begin{array}{l}\text { Online Resources } \\
\text { PowerPoint Presentations with Voice Over } \\
\text { Download of MPss was usefful } \\
\text { Drag-n-Drop features useful }\end{array}$} & & 1 & 2 & 3 & 4 & 5 & \\
\hline & $0.0 \%$ & $0.0 \%$ & $0.0 \%$ & $10.0 \%$ & $20.0 \%$ & $70.0 \%$ & $0.0 \%$ \\
\hline & $\begin{array}{ll}0.0 \% \\
0.0 \%\end{array}$ & $\begin{array}{ll}0.0 \% \\
0.0 \%\end{array}$ & $\frac{10.0 \%}{0.0 \%}$ & \begin{tabular}{c|c}
$0.0 \%$ \\
$10.0 \%$
\end{tabular} & $\begin{array}{c}20.0 \% \\
0.0 \% \\
\end{array}$ & $\frac{60.0 \%}{30.0 \%}$ & $\begin{array}{l}10.0 \% \\
60.0 \% \\
\end{array}$ \\
\hline & $0.0 \%$ & & $0.00 \%$ & $10.0 \%$ & & & \\
\hline $\begin{array}{l}\text { Activity questions challenging and helpful for testing your knowledge } \\
\text { Discussions }\end{array}$ & $0.0 \%$ & $0.0 \%$ & $0.0 \%$ & & $20.0 \%$ & 50.0\% & $20.0 \%$ \\
\hline \multirow{2}{*}{$\begin{array}{l}\text { Discussions } \\
\text { Clinical Rotations } \\
\text { Textbook }\end{array}$} & $20.0 \%$ & $0.0 \%$ & $30.0 \%$ & $\frac{10.0 \%}{0.0 \%}$ & $\frac{10.0 \%}{10.0 \%}$ & $20.0 \%$ & $\frac{10.0 \%}{0.0 \%}$ \\
\hline & $0.0 \%$ & $0.0 \%$ & $0.0 \%$ & $0.0 \%$ & $30.0 \%$ & $70.0 \%$ & $0.0 \%$ \\
\hline $\begin{array}{l}\text { Textbook } \\
\text { Course Objectives } \\
\end{array}$ & $0.0 \%$ & $0.0 \%$ & $0.0 \%$ & $20.0 \%$ & $10.0 \%$ & $70.0 \%$ & $0.0 \%$ \\
\hline \multirow{2}{*}{ Evolve Assignment } & $0.0 \%$ & $0.0 \%$ & $0.0 \%$ & $10.0 \%$ & $30.0 \%$ & $50.0 \%$ & $10.0 \%$ \\
\hline & $0.0 \%$ & $0.0 \%$ & $0.0 \%$ & $10.0 \%$ & $10.0 \%$ & $30.0 \%$ & $50.0 \%$ \\
\hline $\begin{array}{l}\text { Delmar Skills } \\
\text { Readings - Audio Summaries/Lectures }\end{array}$ & $0.0 \%$ & $0.0 \%$ & $0.0 \%$ & $10.0 \%$ & $30.0 \%$ & $60.0 \%$ & $0.0 \%$ \\
\hline $\begin{array}{l}\text { Readings - Audio Summaries/Lectures } \\
\text { Study Guide }\end{array}$ & $0.0 \%$ & $0.0 \%$ & $0.0 \%$ & $10.0 \%$ & $40.0 \%$ & $30.0 \%$ & $20.0 \%$ \\
\hline $\begin{array}{l}\text { Assignments } \\
\text { Onlife technologies used in vour online courses }\end{array}$ & $0.0 \%$ & & & $40.0 \%$ & $30.0 \%$ & $20.0 \%$ & $0.0 \%$ \\
\hline \multirow{2}{*}{$\begin{array}{l}\text { Online technologies used in your online courses } \\
\text { Darton Tech Support M_F ( } 8 \text { am - 8pm) } \\
\end{array}$} & $\frac{0.0 \%}{0.0 \%}$ & $0.0 \%$ & $0.0 \%$ & $0.0 \%$ & $0.0 \%$ & $\frac{40.0 \%}{40.0 \%}$ & $60.0 \%$ \\
\hline & $0.0 \%$ & $\frac{0.0 \%}{10.0 \%}$ & $0.0 \%$ & 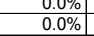 & $0.0 \%$ & $50.0 \%$ & $\frac{60.0 \%}{40.0 \%}$ \\
\hline 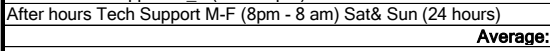 & $1.3 \%$ & $1.3 \%$ & $2.5 \%$ & $8.8 \%$ & $16.3 \%$ & $48.8 \%$ & $21.3 \%$ \\
\hline Mentoring & 0 & 1 & 2 & 3 & 4 & 5 & N/A \\
\hline
\end{tabular}




\begin{tabular}{|c|c|c|c|c|c|c|c|}
\hline \multicolumn{8}{|c|}{ Spring 2013 Semester -Women-Child NURS 2111 - Traditional II } \\
\hline & Very Easy & Somewhat Easy & $\begin{array}{l}\text { Somewhat } \\
\text { Difficylt }\end{array}$ & $\begin{array}{l}\text { Very } \\
\text { Difficut }\end{array}$ & & & \\
\hline \multirow[t]{2}{*}{ Was the course easy to navigate? } & $50.0 \%$ & $50.0 \%$ & $0.0 \%$ & $0.0 \%$ & $100.0 \%$ & & \\
\hline & Definitely & Very Likely & $\begin{array}{c}\text { Somewhat } \\
\text { Likely }\end{array}$ & Unlikely & $\begin{array}{c}\text { Very } \\
\text { unlikely }\end{array}$ & & \\
\hline \multirow[t]{2}{*}{ Would you recommend this course to a fellow student? } & $70.0 \%$ & $30.0 \%$ & $0.0 \%$ & $0.0 \%$ & $0.0 \%$ & & \\
\hline & & & & & & & \\
\hline Was the online system easy to use? & Always & Often & Occasionally & Rarely & Never & N/A & $\begin{array}{l}\text { skipped } \\
\text { question }\end{array}$ \\
\hline Was the written material in the course modules thorough? & $60.0 \%$ & $40.0 \%$ & $0.0 \%$ & $0.0 \%$ & $0.0 \%$ & $0.0 \%$ & \\
\hline \multirow{2}{*}{$\begin{array}{l}\text { Was the module content clear, organized and easy to follow? } \\
\text { Were the directions for the assignments detailed enough to allow you } \\
\text { to complete the work successfully? }\end{array}$} & $60.0 \%$ & $40.0 \%$ & $0.0 \%$ & $0.0 \%$ & $0.0 \%$ & $0.0 \%$ & \\
\hline & $50.0 \%$ & $50.0 \%$ & $0.0 \%$ & $0.0 \%$ & $0.0 \%$ & $0.0 \%$ & \\
\hline The online system as a whole was easy to use. & $40.0 \%$ & $50.0 \%$ & $10.0 \%$ & $0.0 \%$ & $0.0 \%$ & $0.0 \%$ & \\
\hline \multirow{2}{*}{$\begin{array}{l}\text { The email system was sufficient for communications. } \\
\text { The online Help Desk provided timely and satisfactory technical }\end{array}$} & $33.3 \%$ & $55.6 \%$ & $11.1 \%$ & $0.0 \%$ & $0.0 \%$ & $0.0 \%$ & \\
\hline & $30.0 \%$ & $20.0 \%$ & $0.0 \%$ & $0.0 \%$ & $0.0 \%$ & $50.0 \%$ & \\
\hline \multirow{2}{*}{ Average } & $45.6 \%$ & $42.6 \%$ & $3.5 \%$ & $0.0 \%$ & $0.0 \%$ & $8.3 \%$ & \\
\hline & & & & & & & \\
\hline Did the instructors respond and present material well? & Always & Usually & Sometimes & Never & & & \\
\hline $\begin{array}{l}\text { When problems or questions arose, did your instructor respond in a } \\
\text { timely fashion? }\end{array}$ & $70.0 \%$ & $30.0 \%$ & $0.0 \%$ & $0.0 \%$ & & & \\
\hline \multirow{5}{*}{$\begin{array}{l}\text { Did your instructor clearly explain student expectations? } \\
\text { Did your instructor show enthusiasm for the subject matter? } \\
\text { Were you satisfied with how your instructor presented the material? }\end{array}$} & $80.0 \%$ & $20.0 \%$ & $0.0 \%$ & $0.0 \%$ & & & \\
\hline & $80.0 \%$ & $20.0 \%$ & $0.0 \%$ & $0.0 \%$ & & & \\
\hline & $90.0 \%$ & $10.0 \%$ & $0.0 \%$ & $0.0 \%$ & & & \\
\hline & $80.0 \%$ & $20.0 \%$ & $0.0 \%$ & $0.0 \%$ & & & \\
\hline & Definitely & Very Likely & \begin{tabular}{c|c} 
Somewhat \\
Likely
\end{tabular} & Unlikely & \begin{tabular}{c|c|c|} 
Very \\
unlikely
\end{tabular} & & \\
\hline \multirow[t]{3}{*}{ Would you take another course from your instructor? } & $70.0 \%$ & $30.0 \%$ & $0.0 \%$ & $0.0 \%$ & $0.0 \%$ & & \\
\hline & & & & & & & \\
\hline & Excellent & Good & Average & Poor & & & \\
\hline $\begin{array}{l}\text { How successful was this class overall in familiarizing you with the } \\
\text { nursing field and vocabulary? }\end{array}$ & $70.0 \%$ & $30.0 \%$ & $0.0 \%$ & $0.0 \%$ & & & \\
\hline \multirow{4}{*}{$\begin{array}{l}\text { Online Resources } \\
\text { PowerPoint Presentations with Voice Over } \\
\text { Download of MP3s was useful } \\
\text { Drag-n-Drop features useful }\end{array}$} & & 1 & 2 & 3 & 4 & & N/A \\
\hline & $0.0 \%$ & $0.0 \%$ & $0.0 \%$ & $0.0 \%$ & $50.0 \%$ & $40.0 \%$ & $10.0 \%$ \\
\hline & $0.0 \%$ & $0.0 \%$ & $0.0 \%$ & $0.0 \%$ & $40.0 \%$ & $40.0 \%$ & $20.0 \%$ \\
\hline & $0.0 \%$ & $0.0 \%$ & $0.0 \%$ & $10.0 \%$ & $0.0 \%$ & $30.0 \%$ & $60.0 \%$ \\
\hline \multirow{2}{*}{$\begin{array}{l}\text { Activity questions challenging and helpful for testing your knowledge } \\
\text { Discussions }\end{array}$} & $0.0 \%$ & $0.0 \%$ & $0.0 \%$ & $0.0 \%$ & $50.0 \%$ & $30.0 \%$ & $20.0 \%$ \\
\hline & $10.0 \%$ & $10.0 \%$ & $10.0 \%$ & $0.0 \%$ & $40.0 \%$ & $0.0 \%$ & $30.0 \%$ \\
\hline Clinical Rotations & $0.0 \%$ & $0.0 \%$ & $0.0 \%$ & $10.0 \%$ & $10.0 \%$ & $80.0 \%$ & $0.0 \%$ \\
\hline Textbook & $0.0 \%$ & $0.0 \%$ & $0.0 \%$ & $0.0 \%$ & $50.0 \%$ & $40.0 \%$ & $10.0 \%$ \\
\hline \multirow{2}{*}{$\begin{array}{l}\text { Course Objectives } \\
\text { Evolve Assignment }\end{array}$} & $0.0 \%$ & $0.0 \%$ & $0.0 \%$ & $10.0 \%$ & $40.0 \%$ & $40.0 \%$ & $10.0 \%$ \\
\hline & $0.0 \%$ & $0.0 \%$ & $0.0 \%$ & $0.0 \%$ & $60.0 \%$ & $30.0 \%$ & $10.0 \%$ \\
\hline $\begin{array}{l}\text { Evolve Assignment } \\
\text { Delmar Skills } \\
\end{array}$ & $0.0 \%$ & $0.0 \%$ & $0.0 \%$ & $30.0 \%$ & $30.0 \%$ & $0.0 \%$ & $40.0 \%$ \\
\hline $\begin{array}{l}\text { Delmar Skills } \\
\text { Readings - Audio Summaries/Lectures }\end{array}$ & $0.0 \%$ & $0.0 \%$ & $0.0 \%$ & $0.0 \%$ & $33.3 \%$ & $55.6 \%$ & $11.1 \%$ \\
\hline $\begin{array}{l}\text { Study Guide } \\
\text { Assignments }\end{array}$ & $0.0 \%$ & $\frac{0.0 \%}{10.0 \%}$ & o. $0.0 \%$ & $\frac{10.0 \%}{20.0 \%}$ & $50.0 \%$ & $30.0 \%$ & $\frac{10.0 \%}{10.0 \%}$ \\
\hline $\begin{array}{l}\text { Assignments } \\
\text { Online technologies used in your online courses }\end{array}$ & $0.0 \%$ & $0.0 \%$ & $0.0 \%$ & $10.0 \%$ & $60.0 \%$ & $30.0 \%$ & $0.0 \%$ \\
\hline Darton Tech Support M_F (8am - 8pm) & $0.0 \%$ & $0.0 \%$ & $0.0 \%$ & $0.0 \%$ & $10.0 \%$ & $30.0 \%$ & $60.0 \%$ \\
\hline After hours Tech Support M-F (8pm - 8 am) Sat\& Sun (24 hours) & $0.0 \%$ & $0.0 \%$ & $0.0 \%$ & $0.0 \%$ & $0.0 \%$ & $30.0 \%$ & $70.0 \%$ \\
\hline Average: & $0.6 \%$ & $1.3 \%$ & $0.6 \%$ & $6.3 \%$ & $35.2 \%$ & $32.9 \%$ & $23.2 \%$ \\
\hline Mentoring & & 1 & 2 & 3 & & 5 & N/A \\
\hline Mentoring/Help sessions & $0.0 \%$ & $10.0 \%$ & $0.0 \%$ & $0.0 \%$ & $0.0 \%$ & $50.0 \%$ & $40.0 \%$ \\
\hline
\end{tabular}




\begin{tabular}{|c|c|c|c|c|c|c|c|}
\hline \multicolumn{8}{|c|}{ Online Survey Summary for Summer 2013 Semester - Summary of all three courses } \\
\hline & Very Easy & Somewhat Easy & $\begin{array}{c}\text { Somewhat } \\
\text { Difficult }\end{array}$ & $\begin{array}{l}\text { Very } \\
\text { Difficult }\end{array}$ & & & \\
\hline Was the course easy to navigate? & $51.8 \%$ & $38.9 \%$ & $9.3 \%$ & $0.0 \%$ & $100.0 \%$ & & \\
\hline & Definitely & Very Likely & $\begin{array}{c}\text { Somewhat } \\
\text { Likely }\end{array}$ & Unlikely & \begin{tabular}{c|c} 
Very \\
unlikely
\end{tabular} & & \\
\hline Would you recommend this course to a fellow student? & $61.1 \%$ & $21.3 \%$ & $11.1 \%$ & $6.5 \%$ & $0.0 \%$ & $100.0 \%$ & \\
\hline Was the online system easy to use? & Always & Often & Occasionally & Rarely & Never & N/A & \\
\hline Was the written material in the course modules thorough? & $59.3 \%$ & $15.7 \%$ & $18.5 \%$ & $6.5 \%$ & $0.0 \%$ & & \\
\hline Was the module content clear, organized and easy to follow? & $50.5 \%$ & $27.8 \%$ & $19.0 \%$ & $2.8 \%$ & $0.0 \%$ & & \\
\hline $\begin{array}{l}\text { Were the directions for the assignments detailed enough to allow you to } \\
\text { complete the work successfully? }\end{array}$ & $53.8 \%$ & $27.4 \%$ & $15.8 \%$ & $3.0 \%$ & $0.0 \%$ & & \\
\hline The online system as a whole was easy to use. & $40.7 \%$ & $30.5 \%$ & $25.3 \%$ & $3.7 \%$ & $0.0 \%$ & & \\
\hline The email system was sufficient for communications. & $53.7 \%$ & $42.6 \%$ & $3.7 \%$ & $0.0 \%$ & $0.0 \%$ & & \\
\hline $\begin{array}{l}\text { The online Help Desk provided timely and satisfactory technical } \\
\text { assistance. }\end{array}$ & $6.9 \%$ & $6.8 \%$ & $11.6 \%$ & $3.7 \%$ & $3.7 \%$ & $67.5 \%$ & \\
\hline $\begin{array}{ll} & \text { Average: }\end{array}$ & $44.1 \%$ & $25.1 \%$ & $15.7 \%$ & $3.3 \%$ & $0.6 \%$ & & \\
\hline & & & & & & & \\
\hline Did the instructors respond and present material well? & Always & Usually & Sometimes & Never & & & \\
\hline $\begin{array}{l}\text { When problems or questions arose, did your instructor respond in a } \\
\text { timely fashion? }\end{array}$ & $75.0 \%$ & $21.3 \%$ & $3.7 \%$ & $0.0 \%$ & & & \\
\hline Did your instructor clearly explain student expectations? & $75.0 \%$ & $21.3 \%$ & $3.7 \%$ & $0.0 \%$ & & & \\
\hline Did your instructor show enthusiasm for the subject matter? & $85.2 \%$ & $11.1 \%$ & $3.7 \%$ & $0.0 \%$ & & & \\
\hline Were you satisfied with how your instructor presented the material? & $63.0 \%$ & $27.8 \%$ & $9.3 \%$ & $0.0 \%$ & & & \\
\hline Average: & $74.5 \%$ & $20.4 \%$ & $5.1 \%$ & $0.0 \%$ & & & \\
\hline & Definitely & Very Likely & $\begin{array}{l}\text { Somewhat } \\
\text { Likely }\end{array}$ & Unlikely & $\begin{array}{l}\text { Very } \\
\text { unlikely }\end{array}$ & & \\
\hline Would you take another course from your instructor? & $85.2 \%$ & $8.3 \%$ & $2.8 \%$ & $3.7 \%$ & $0.0 \%$ & & \\
\hline $\begin{array}{l}\text { How successful was this class overall in familiarizing you with the } \\
\text { nursing field and vocabulary? }\end{array}$ & Excellent & Good & Average & Poor & & & \\
\hline & $61.1 \%$ & $22.2 \%$ & $0.0 \%$ & $12.5 \%$ & & & \\
\hline Online Resources & 0 & 1 & 2 & 3 & 4 & 5 & N/A \\
\hline PowerPoint Presentations with Voice Over & $3.7 \%$ & $0.0 \%$ & $0.0 \%$ & $5.6 \%$ & $29.6 \%$ & $53.7 \%$ & $7.4 \%$ \\
\hline Download of MP3s was useful & $6.5 \%$ & $0.0 \%$ & $2.8 \%$ & $9.3 \%$ & $31.5 \%$ & $35.2 \%$ & $14.8 \%$ \\
\hline Drag-n-Drop features useful & $6.7 \%$ & $0.0 \%$ & $0.0 \%$ & $6.7 \%$ & $3.0 \%$ & $10.4 \%$ & $73.1 \%$ \\
\hline Activity questions challenging and helpful for testing your knowledge & $6.5 \%$ & $0.0 \%$ & $0.0 \%$ & $14.8 \%$ & $16.7 \%$ & $58.7 \%$ & $3.7 \%$ \\
\hline Discussions & $6.5 \%$ & $7.4 \%$ & $2.8 \%$ & $14.8 \%$ & $13.0 \%$ & $51.9 \%$ & $3.7 \%$ \\
\hline Clinical Rotations & $3.7 \%$ & $3.7 \%$ & $0.0 \%$ & $2.8 \%$ & $0.0 \%$ & $67.6 \%$ & $22.6 \%$ \\
\hline Textbook & $3.7 \%$ & $2.8 \%$ & $16.7 \%$ & $16.7 \%$ & $17.6 \%$ & $42.6 \%$ & $0.0 \%$ \\
\hline Course Objectives & $6.9 \%$ & $0.0 \%$ & $13.4 \%$ & $5.6 \%$ & $26.8 \%$ & $47.2 \%$ & $0.0 \%$ \\
\hline Evolve Assignment & $6.5 \%$ & $0.0 \%$ & $6.5 \%$ & $5.6 \%$ & $9.3 \%$ & $16.7 \%$ & $55.6 \%$ \\
\hline ATI Assignments & $3.7 \%$ & $0.0 \%$ & $5.6 \%$ & $22.2 \%$ & $15.7 \%$ & $52.8 \%$ & $0.0 \%$ \\
\hline Readings - Audio Summaries/Lectures & $4.2 \%$ & $0.0 \%$ & $4.2 \%$ & $15.3 \%$ & $27.3 \%$ & $44.9 \%$ & $4.2 \%$ \\
\hline Study Guide & $6.5 \%$ & $0.0 \%$ & $7.4 \%$ & $6.5 \%$ & $18.5 \%$ & $49.1 \%$ & $12.0 \%$ \\
\hline Assignments & $3.7 \%$ & $0.0 \%$ & $6.5 \%$ & $7.4 \%$ & $24.1 \%$ & $58.4 \%$ & $0.0 \%$ \\
\hline Online technologies used in your online courses & $4.2 \%$ & $0.0 \%$ & $4.2 \%$ & $10.2 \%$ & $25.0 \%$ & $46.7 \%$ & $9.7 \%$ \\
\hline Darton Tech Support M_F (8am - 8pm) & $3.7 \%$ & $0.0 \%$ & $0.0 \%$ & $3.7 \%$ & $2.8 \%$ & $2.8 \%$ & $87.0 \%$ \\
\hline After hours Tech Support M-F (8pm - 8 am) Sat\& Sun (24 hours) & $3.7 \%$ & $0.0 \%$ & $0.0 \%$ & $3.7 \%$ & $2.8 \%$ & $0.0 \%$ & $89.8 \%$ \\
\hline Average: & $5.0 \%$ & $0.9 \%$ & $4.4 \%$ & $9.4 \%$ & $16.5 \%$ & $39.9 \%$ & $24.0 \%$ \\
\hline & & & & & & & \\
\hline Mentoring & 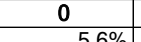 & 0 & $00 \%$ & \begin{tabular}{l|l|l}
3 & -10 \\
\end{tabular} & \begin{tabular}{l|l}
4 \\
$00 \%$
\end{tabular} & \begin{tabular}{l|l|l}
5 \\
$535 \%$
\end{tabular} & N/A \\
\hline
\end{tabular}




\begin{tabular}{|c|c|c|c|c|c|c|c|c|c|c|c|c|c|c|c|c|c|c|c|c|c|}
\hline \multicolumn{22}{|l|}{ Phone Interview Summary of Ratings - Fall 2012} \\
\hline & Online quizzes & $\begin{array}{c}\text { Voice over } \\
\text { PPT } \\
\text { Present. }\end{array}$ & $\begin{array}{l}\text { Online } \\
\text { Lectures }\end{array}$ & $\begin{array}{c}\begin{array}{c}\text { Practice } \\
\text { Exams }\end{array} \\
\text {. }\end{array}$ & $\begin{array}{c}\text { Practice } \\
\text { Worksheets }\end{array}$ & $\begin{array}{l}\text { Video } \\
\text { Tutorials }\end{array}$ & $\begin{array}{l}\text { Course } \\
\text { Calendar }\end{array}$ & Bulletin Board & E-Mail & $\begin{array}{c}\text { Discussion } \\
\text { Threads }\end{array}$ & Lab Sessions & $\begin{array}{c}\text { Lab Lectures } \\
\text { Videos }\end{array}$ & $\begin{array}{l}\text { Clinical } \\
\text { Videos }\end{array}$ & $\begin{array}{c}\text { Course } \\
\text { objectives }\end{array}$ & $\begin{array}{l}\text { Evolve } \\
\text { Assign. }\end{array}$ & \begin{tabular}{|c|} 
Readings \\
Link to \\
Overview of \\
Chapters
\end{tabular} & Study Guide & Assign. & $\begin{array}{c}\text { Multimedia } \\
\text { Math } \\
\text { Solutions }\end{array}$ & $\begin{array}{c}\text { Self- } \\
\text { Assessment } \\
\text { Tools }\end{array}$ & $\begin{array}{l}\text { Overall } \\
\text { Average }\end{array}$ \\
\hline \multicolumn{22}{|l|}{ Traditional Cohort II } \\
\hline \multicolumn{22}{|l|}{ Adult Health II NURS 1112} \\
\hline $\begin{array}{l}\text { Averages: } \\
\end{array}$ & 4.25 & 4.25 & 4.00 & 4.67 & 4.40 & 3.14 & 4.88 & 3.80 & 4.38 & 2.00 & 4.71 & 4.71 & 4.57 & 3.63 & 3.88 & 4.00 & 4.14 & 3.88 & 3.75 & 4.63 & 4.08 \\
\hline \multicolumn{22}{|l|}{ Psychiatric Nursing NURS 2113} \\
\hline Averages: & 4.00 & 4.00 & 3.86 & 4.33 & 4.40 & 4.14 & 4.43 & 4.17 & 4.29 & 3.17 & 4.25 & 4.17 & 4.25 & 3.71 & 4.71 & 4.14 & 4.29 & 4.29 & 4.00 & 4.00 & 4.13 \\
\hline \multicolumn{22}{|l|}{ Bridge Cohort II } \\
\hline \multicolumn{22}{|l|}{ Adult Health III NURS 2115} \\
\hline $\begin{array}{l}\text { Averages: } \\
\end{array}$ & 4.33 & 5.00 & 5.00 & 4.67 & 5.00 & 5.00 & 5.00 & 4.50 & 5.00 & 4.33 & 5.00 & 5.00 & 5.00 & 4.67 & 4.67 & 4.75 & 5.00 & 4.67 & 4.67 & 4.40 & 4.80 \\
\hline & & & & & & & & & & & & & & & & & & & & & \\
\hline \multicolumn{22}{|l|}{ Bridge Cohort III } \\
\hline \multicolumn{22}{|l|}{ Fundamentals/Nursing NURS 1301} \\
\hline Averages: & 4.83 & 4.67 & 4.33 & 4.40 & 4.33 & 4.50 & 4.40 & 5.00 & 5.00 & 3.80 & 4.33 & 4.60 & 5.00 & 4.33 & 4.17 & 4.50 & 5.00 & 4.83 & 5.00 & 4.50 & 4.48 \\
\hline Psychiatric Nursing NURS 2313 & & & & & & & & & & & & & & & & & & & & & \\
\hline Averages: & 4.80 & 3.50 & 3.60 & 4.40 & 4.67 & 4.00 & 4.40 & & 4.80 & 4.00 & 4.00 & 4.00 & 3.00 & 4.17 & 4.17 & 4.80 & 4.67 & 4.50 & 5.00 & 4.50 & 4.25 \\
\hline
\end{tabular}




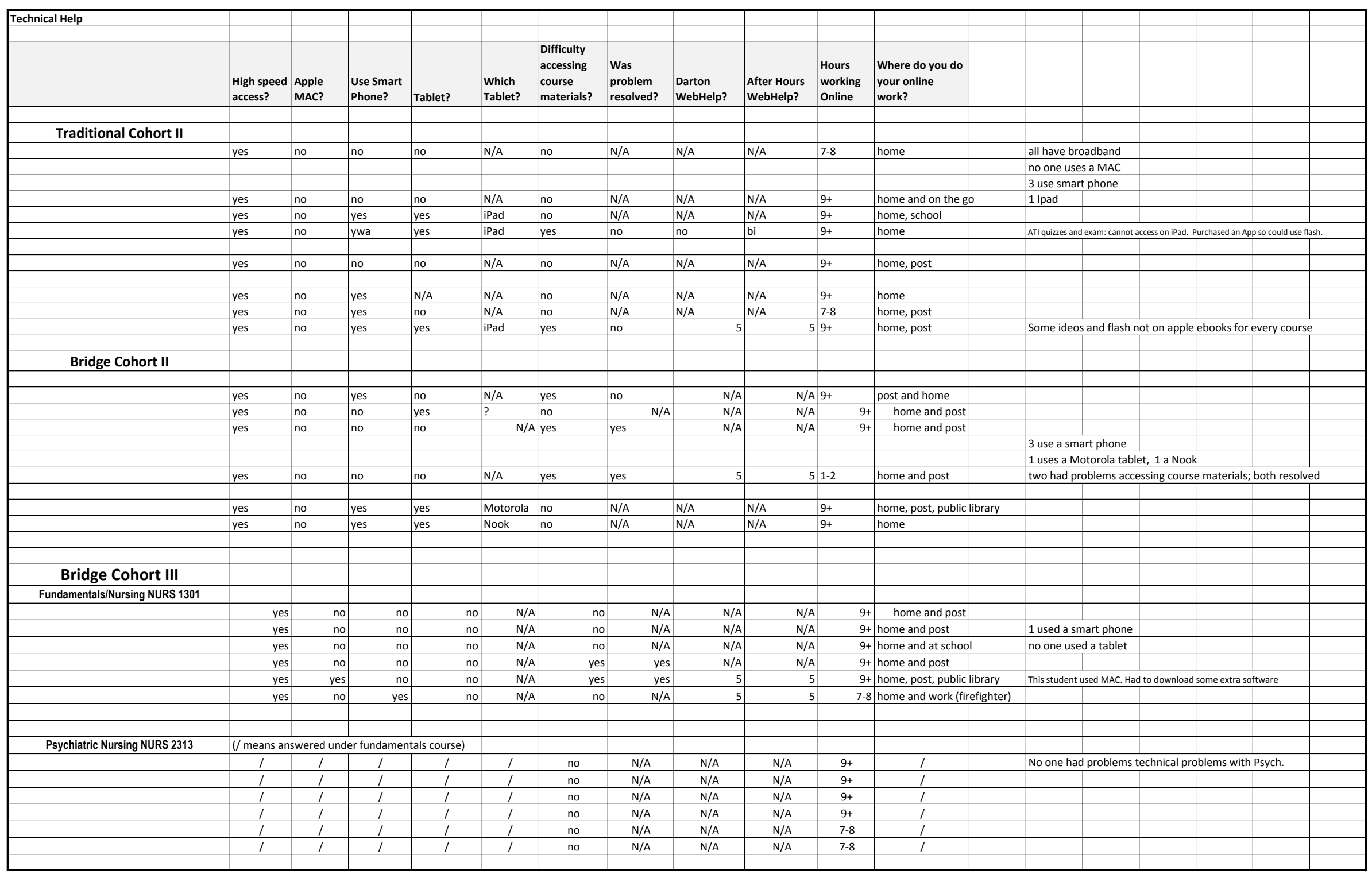




\begin{tabular}{|c|c|c|c|c|c|c|c|c|}
\hline Mentoring & $\begin{array}{c}\text { How } \\
\text { important } \\
\text { was it to your } \\
\text { success? }\end{array}$ & Time Mgmt. & $\begin{array}{c}\text { Study } \\
\text { Techniques }\end{array}$ & $\begin{array}{l}\text { Test taking } \\
\text { Techniques }\end{array}$ & $\begin{array}{c}\text { Use of } \\
\text { Web } \\
\text { resources }\end{array}$ & $\begin{array}{c}\text { Course } \\
\text { Content } \\
\text { Reviews, } \\
\text { Tutoring, } \\
\text { Small } \\
\text { Group } \\
\text { Sessions }\end{array}$ & $\begin{array}{l}\text { Individual } \\
\text { Guidance or } \\
\text { Assistance }\end{array}$ & $\begin{array}{c}\text { Overall } \\
\text { Average }\end{array}$ \\
\hline \multicolumn{9}{|l|}{ Traditional Cohort II } \\
\hline & 5 & 5 & 5 & 5 & 5 & 4 & 5 & \\
\hline & 5 & $\mathrm{~N} / \mathrm{A}$ & $\mathrm{N} / \mathrm{A}$ & $\mathrm{N} / \mathrm{A}$ & $\mathrm{N} / \mathrm{A}$ & $\mathrm{N} / \mathrm{A}$ & 5 & \\
\hline & 4 & 5 & 5 & 4 & 4 & 5 & 4 & \\
\hline & $\mathrm{N} / \mathrm{A}$ & $\mathrm{N} / \mathrm{A}$ & $\mathrm{N} / \mathrm{A}$ & $\mathrm{N} / \mathrm{A}$ & $\mathrm{N} / \mathrm{A}$ & N/A & 5 & \\
\hline & 4 & 5 & 5 & 5 & 5 & 5 & 5 & \\
\hline & 5 & 5 & 5 & 5 & 5 & 4 & 4 & \\
\hline & 5 & 5 & 5 & 4 & 5 & 5 & 5 & \\
\hline & $\mathrm{N} / \mathrm{A}$ & 4.00 & 4 & 3 & 4 & 5 & 5 & \\
\hline Averages: & 4.67 & 4.83 & 4.83 & 4.33 & 4.67 & 4.67 & 4.75 & 4.68 \\
\hline & & & & & & & & \\
\hline \multicolumn{9}{|l|}{ Bridge Cohort II } \\
\hline & $\mathrm{N} / \mathrm{A}$ & $\mathrm{N} / \mathrm{A}$ & $\mathrm{N} / \mathrm{A}$ & $\mathrm{N} / \mathrm{A}$ & $\mathrm{N} / \mathrm{A}$ & $\mathrm{N} / \mathrm{A}$ & N/A & \\
\hline & 2 & 2 & 4 & 2 & $\mathrm{~N} / \mathrm{A}$ & 3 & N/A & \\
\hline & $\mathrm{N} / \mathrm{A}$ & $\mathrm{N} / \mathrm{A}$ & $\mathrm{N} / \mathrm{A}$ & $\mathrm{N} / \mathrm{A}$ & $\mathrm{N} / \mathrm{A}$ & $\mathrm{N} / \mathrm{A}$ & 4 & \\
\hline & 5 & 5 & 5 & 5 & 5 & 5 & 5 & \\
\hline & $\mathrm{N} / \mathrm{A}$ & $\mathrm{N} / \mathrm{A}$ & $\mathrm{N} / \mathrm{A}$ & $\mathrm{N} / \mathrm{A}$ & $\mathrm{N} / \mathrm{A}$ & 4 & $\mathrm{~N} / \mathrm{A}$ & \\
\hline Averages: & 3.50 & 3.50 & 4.50 & 3.50 & 5.00 & 4.00 & 4.50 & 4.07 \\
\hline & & & & & & & & \\
\hline & & & & & & & & \\
\hline Bridge Cohort III & & \multicolumn{7}{|c|}{ Ms. Inandan visited this group on February 27 . Received report after phone calls were made. } \\
\hline
\end{tabular}




\begin{tabular}{|c|c|c|c|c|c|c|}
\hline \multicolumn{7}{|l|}{ Student Services } \\
\hline & Advising & Registration & Fee Payment & Bookstore & $\begin{array}{l}\text { Grant } \\
\text { Office }\end{array}$ & $\begin{array}{l}\text { Overall } \\
\text { Average }\end{array}$ \\
\hline \multicolumn{7}{|l|}{ Traditional Cohort II } \\
\hline & N/A & 4 & 4 & 4 & 5 & \\
\hline & 5 & 5 & $\mathrm{~N} / \mathrm{A}$ & 5 & 5 & \\
\hline & 5 & 5 & 5 & 5 & $\mathrm{~N} / \mathrm{A}$ & \\
\hline & 4 & 4 & 2 & $\mathrm{~N} / \mathrm{A}$ & $\mathrm{N} / \mathrm{A}$ & \\
\hline & N/A & 5 & 5 & $\mathrm{~N} / \mathrm{A}$ & 5 & \\
\hline & 5 & 4 & 5 & 5 & 5 & 5 \\
\hline & 5 & 5 & 5 & $\mathrm{~N} / \mathrm{A}$ & 5 & \\
\hline & 5.00 & 5.00 & 5.00 & $\mathrm{~N} / \mathrm{A}$ & 3.00 & \\
\hline Averages: & 4.83 & 4.63 & 4.43 & 4.75 & 4.67 & 4.66 \\
\hline \multicolumn{7}{|l|}{ Bridge Cohort II } \\
\hline & 5 & 5 & 5 & $\mathrm{~N} / \mathrm{A}$ & N/A & \\
\hline & 4 & 5 & 4 & $\mathrm{~N} / \mathrm{A}$ & N/A & \\
\hline & 5 & 5 & 5 & 5 & 5 & \\
\hline & 5 & 5 & 5 & $\mathrm{~N} / \mathrm{A}$ & 5 & \\
\hline & 5 & 5 & 5 & $\mathrm{~N} / \mathrm{A}$ & 5 & \\
\hline \multirow[t]{3}{*}{ Averages: } & 4.80 & 5.00 & 4.80 & 5.00 & 5.00 & 4.92 \\
\hline & | & \begin{tabular}{l|l} 
& \\
\end{tabular} & 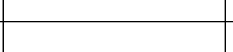 & 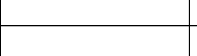 & . & . \\
\hline & Advising & Registration & Fee Payment & Bookstore & $\begin{array}{l}\text { Grant } \\
\text { Office }\end{array}$ & $\begin{array}{l}\text { Overall } \\
\text { Average }\end{array}$ \\
\hline \multicolumn{7}{|l|}{ Bridge Cohort III } \\
\hline & 5 & 5 & 5 & $\mathrm{~N} / \mathrm{A}$ & $\mathrm{N} / \mathrm{A}$ & \\
\hline & 5 & 3 & 4 & 4 & 5 & \\
\hline & 5 & 5 & 4 & 4 & N/A & \\
\hline & 5 & 3 & 4 & 4 & 5 & \\
\hline & 5 & 5 & 5 & 5 & 5 & \\
\hline \multirow[t]{2}{*}{ Averages: } & 5 & 4.2 & 4.4 & 4.25 & 5 & 4.57 \\
\hline & & & & & 4.84 & \\
\hline
\end{tabular}




\begin{tabular}{|c|c|c|c|c|c|c|c|c|c|c|c|c|c|c|c|c|c|c|c|c|c|}
\hline \multicolumn{22}{|c|}{ Phone Interview Summary of Ratings - Spring 2013} \\
\hline & Online quizzes & $\begin{array}{c}\text { Voice over } \\
\text { PPT } \\
\text { Present. } \\
\end{array}$ & $\begin{array}{l}\text { Online } \\
\text { Lectures }\end{array}$ & $\begin{array}{c}\begin{array}{c}\text { Practice } \\
\text { Exams }\end{array} \\
\text {. }\end{array}$ & $\begin{array}{c}\text { Practice } \\
\text { Worksheets }\end{array}$ & $\begin{array}{l}\text { Video } \\
\text { Tutorials }\end{array}$ & $\begin{array}{l}\text { Course } \\
\text { Calendar }\end{array}$ & Bulletin Board & E-Mail & $\begin{array}{c}\text { Discussion } \\
\text { Threads }\end{array}$ & Lab Sessions & $\begin{array}{c}\text { Lab Lectures } \\
\text { Videos }\end{array}$ & $\begin{array}{l}\text { Clinical } \\
\text { Videos }\end{array}$ & $\begin{array}{c}\text { Course } \\
\text { objectives }\end{array}$ & $\begin{array}{l}\text { Evolve } \\
\text { Assign. }\end{array}$ & \begin{tabular}{|c|} 
Readings \\
Link to \\
Overview of \\
Chapters \\
\end{tabular} & Study Guide & Assign. & $\begin{array}{c}\text { Multimedia } \\
\text { Math } \\
\text { Solutions }\end{array}$ & $\begin{array}{c}\text { Self- } \\
\text { Assessment } \\
\text { Tools } \\
\end{array}$ & $\begin{array}{c}\text { Overall } \\
\text { Average }\end{array}$ \\
\hline \multicolumn{22}{|l|}{ Traditional Cohort II } \\
\hline Nursing Care/Women/Child NURS 2117 & 4.00 & 4.75 & 4.00 & $\begin{array}{c}4.33 \\
\end{array}$ & 4.40 & 4.25 & 4.60 & 4.50 & 5.00 & 2.00 & 4.80 & \begin{tabular}{c|c}
.75 \\
\end{tabular} & 4.75 & 4.25 & 4.75 & 4.40 & 4.50 & 3.80 & 3.00 & 4.50 & 4.46 \\
\hline Nursing Leadership NURS 2117 & 3.75 & 4.00 & 4.00 & 4.00 & 4.25 & 5.00 & 4.60 & 5.00 & 4.25 & 3.00 & 3.67 & 2.00 & 4.00 & 4.50 & 3.50 & 4.25 & 3.75 & 4.00 & 3.00 & 3.75 & 3.91 \\
\hline & & & & & & & & & & & & & & & & & & & & & \\
\hline \multicolumn{22}{|l|}{ Traditional Cohort III } \\
\hline 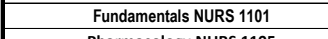 & 4.80 & 4.43 & 4.14 & 4.00 & 3.75 & 4.43 & 4.14 & 4.25 & 4.43 & 3.67 & 4.83 & 4.83 & 4.67 & 4.00 & 4.00 & 3.20 & \begin{tabular}{l|l}
4.67 \\
\end{tabular} & 4.43 & 4.00 & 3.50 & 4.24 \\
\hline Pharmacology NURS 1105 & 4.40 & 4.50 & 4.67 & 4.50 & 4.33 & 4.33 & 4.67 & 4.67 & 4.60 & 3.00 & 5.00 & 4.00 & 4.40 & 4.33 & 4.33 & 4.33 & 4.67 & 4.33 & 4.50 & 4.33 & 4.43 \\
\hline & & & & & & & & & & & & & & & & & & & & & \\
\hline \multicolumn{22}{|l|}{ Bridge Cohort III } \\
\hline \multirow{4}{*}{ Pharmacology NURS 1105} & \begin{tabular}{l|l|}
4.75 \\
4.75
\end{tabular} & $\begin{array}{c}4.50 \\
.50\end{array}$ & 4.38 & $\begin{array}{ll}4.43 \\
.50\end{array}$ & 4.00 & 3.86 & 4.25 & 3.50 & 4.75 & 3.50 & 4.13 & 4.57 & 4.40 & 4.00 & 4.50 & 4.00 & 4.88 & 4.63 & 4.00 & 4.00 & 4.25 \\
\hline & 4.75 & 4.50 & 4.57 & 5.00 & 4.40 & \begin{tabular}{l|l}
4.33 \\
\end{tabular} & \begin{tabular}{l|l}
4.75 \\
\end{tabular} & 5.00 & 4.88 & 3.50 & $\begin{array}{l}4.20 \\
\end{array}$ & 4.20 & 4.25 & 4.50 & 4.60 & 4.29 & \begin{tabular}{l|l}
4.75 \\
\end{tabular} & \begin{tabular}{l|l}
4.88 \\
\end{tabular} & 4.00 & 4.33 & 4.46 \\
\hline & & & & & & & & & & & & & & & & & & & & & \\
\hline & & & & & & & & & & & & & & & & & & & \multicolumn{2}{|c|}{ Overall average: } & 4.29 \\
\hline
\end{tabular}


Phone Interview Summary of Ratings - Spring 2013

Technical

\begin{tabular}{|l|l|l|l|l|l|l|l|l|}
\hline \multicolumn{2}{|c|}{ Technical } & & & $\begin{array}{l}\text { Difficulty } \\
\text { accessing } \\
\text { course } \\
\text { materials? }\end{array}$ & $\begin{array}{l}\text { Was } \\
\text { problem } \\
\text { resolved? }\end{array}$ & $\begin{array}{l}\text { Darton } \\
\text { WebHelp? }\end{array}$ & $\begin{array}{l}\text { After Hours } \\
\text { WebHelp? }\end{array}$ \\
\hline
\end{tabular}

Traditional Cohort II

\begin{tabular}{|c|c|c|c|c|c|c|c|c|}
\hline \multirow[b]{2}{*}{ Ahedov, Princess } & \multirow[b]{2}{*}{ no } & \multirow[b]{2}{*}{ no } & \multirow[b]{2}{*}{ yes } & \multirow[b]{2}{*}{ MS Surface } & \multirow[b]{2}{*}{ no } & \multirow[b]{2}{*}{ N/A } & \multirow[b]{2}{*}{ N/A } & \multirow[b]{2}{*}{ N/A } \\
\hline & & & & & & & & \\
\hline Bowden, Sidney & No & Yes & No & N/A & no & N/A & N/A & N/A \\
\hline Brown, Beverly & no & no & no & N/A & no & N/A & N/A & N/A \\
\hline \multicolumn{9}{|l|}{ Colburn, Kristin } \\
\hline \multirow{2}{*}{\multicolumn{9}{|c|}{ Crissman, Lauren }} \\
\hline \multicolumn{5}{|l|}{ Daigrepont, Joelle } & & & & \\
\hline Johnson, Veronica & yes & yes & yes & does't know & no & N/A & N/A & N/A \\
\hline Seifert, Jessica & No & yes & no & N/A & Yes & yes & 5 & 5 \\
\hline Tomasie, Kelly & & & & & & & & \\
\hline
\end{tabular}

Traditional Cohort III

Dyer, Jasmine

Escobar, Gustavo

Graves, Kimberly

Hamilton, Kristal

Hutcheson, Henry
Jones, Kimberly

Manges, Kimberly

Norman, Cristin

Rumph, Paulette

Salter, Kristen

Sanders, Conketia

Smith Seleata

no no no N/A no N/A 5 N/A

no no no N/A no N/A N/A

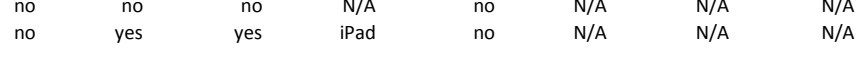

yes yes yes iPad yes yes 5 N/A problem worked out by second module; Darton WebHelp was great.

no no no N/A no N/A N/A N/A

no yes yes iPad yes no N/A N/A iPad problem

\begin{tabular}{|l|l|l|l|l|l|l|l|l|}
\hline & Apple \\
MAC? & $\begin{array}{l}\text { Use Smart } \\
\text { Phone? }\end{array}$ & Tablet? & $\begin{array}{l}\text { Which } \\
\text { Tablet? }\end{array}$ & $\begin{array}{l}\text { Difficulty } \\
\text { accessing } \\
\text { course } \\
\text { materials? }\end{array}$ & $\begin{array}{l}\text { Was } \\
\text { problem } \\
\text { resolved? }\end{array}$ & $\begin{array}{l}\text { Darton } \\
\text { WebHelp? }\end{array}$ & $\begin{array}{l}\text { After Hours } \\
\text { WebHelp? }\end{array}$ \\
\hline
\end{tabular}

Bridge Cohort III

Binion, Lis

Cogdell, Kimberly

Dunford, Albert

Green, Tasha

Hoskins, Pam

Peguero, Giavonni B.

Shorter, Cheryl

Thompson, Marsha

$\begin{array}{cccc}\text { yes } & \text { yes } & \text { yes } & \text { iPad } \\ \text { no } & \text { yes } & \text { yes } & \text { iPad } \\ \text { no } & \text { no } & \text { no } & \text { N/A } \\ & & \text { yes } & \text { iPad } \\ \text { no } & \text { yes } & \text { no } & \text { N/A } \\ \text { no } & \text { no } & & \\ & & \text { yes } & \text { Samsung Galaxie } \\ \text { no } & \text { yes } & \text { yes } & \text { iPad } \\ \text { yes } & \text { no } & \text { yes } & \text { Kindel Fire } \\ \text { no } & \text { yes } & \text { yos }\end{array}$

$\begin{array}{cc}\text { yes } & \text { yes } \\ \text { no } & \text { N/A } \\ \text { yes } & \\ \text { no } & \\ \text { no } & \text { N/A } \\ & \\ \text { yes } & \text { yes } \\ \text { yes } & \text { yes } \\ \text { no } & N / A\end{array}$

$\begin{array}{rrr}\text { yes } & 4 & \text { N/A } \\ \text { N/A } & \text { N/A } & \text { N/A } \\ \text { no } & 3 & 3 \text { PPT never worked, Darton WebHelp and } \\ & & \\ \text { N/A } & \text { N/A } & \text { N/A } \\ \text { N/A } & \text { N/A } & \text { N/A } \\ & & \\ \text { yes } & 3 & 3 \\ \text { yes } & \text { N/A } & \text { N/A On the MAC needed to add something } \\ \text { N/A } & \text { N/A } & \text { N/A } \\ & 4.17 & 3.67 \\ & 6 \text { used WebHelp } \\ & \text { 14 did not use WebHelp } \\ & 3 \text { used After Hours }\end{array}$




\begin{tabular}{|c|c|c|c|c|c|c|c|c|}
\hline Phone Interview Summary of Ratings - Spring 2013 & $\begin{array}{c}\text { How } \\
\text { important } \\
\text { was it to your } \\
\text { success? }\end{array}$ & Time Mgmt. & $\begin{array}{c}\text { Study } \\
\text { Techniques }\end{array}$ & $\begin{array}{l}\text { Test taking } \\
\text { Techniques }\end{array}$ & $\begin{array}{c}\text { Use of } \\
\text { Web } \\
\text { resources }\end{array}$ & $\begin{array}{c}\text { Course } \\
\text { Content } \\
\text { Reviews, } \\
\text { Tutoring, } \\
\text { Small } \\
\text { Group } \\
\text { Sessions }\end{array}$ & $\begin{array}{l}\text { Individual } \\
\text { Guidance or } \\
\text { Assistance }\end{array}$ & $\begin{array}{c}\text { Overall } \\
\text { Average }\end{array}$ \\
\hline \multicolumn{9}{|l|}{ Mentoring } \\
\hline Traditional Cohort II & 5.00 & 5.00 & 4.80 & 4.80 & 4.80 & 5.00 & 5.00 & 4.91 \\
\hline & & & & & & & & \\
\hline Traditional Cohort III & 3.80 & 3.33 & 3.83 & 4.00 & 4.33 & 4.67 & 4.00 & 4.00 \\
\hline & & & & & & & & \\
\hline Bridge Cohort III & 4.33 & 4.67 & 4.67 & 4.00 & 4.00 & 4.17 & 4.60 & 4.35 \\
\hline & & & & & & & & \\
\hline Overall average & 4.38 & 4.33 & 4.43 & 4.27 & 4.38 & 4.61 & 4.53 & 4.42 \\
\hline
\end{tabular}




\begin{tabular}{|c|c|c|c|c|c|c|}
\hline \multicolumn{7}{|l|}{ Phone Interview Summary of Ratings - Spring 2013} \\
\hline Student Services & & & & & & \\
\hline & Advising & Registration & Fee Payment & Bookstore & Grant Office & $\begin{array}{l}\text { Overall } \\
\text { Average }\end{array}$ \\
\hline Traditional Cohort II & 5 & 3.8 & 3.75 & 4.25 & 5 & 4.41 \\
\hline Traditional Cohort III & 4.50 & 4.29 & 4.17 & 5.00 & 4.86 & 4.50 \\
\hline Bridge Cohort III & 4.86 & 4.43 & 4.50 & 5.00 & 4.86 & 4.67 \\
\hline Overall average: & 4.79 & 4.17 & 4.14 & 4.75 & 4.90 & 4.53 \\
\hline
\end{tabular}




\begin{tabular}{|c|c|c|c|c|c|c|c|c|c|c|c|c|c|c|c|c|c|c|c|c|c|}
\hline \multicolumn{22}{|l|}{ Phone Interview Summary of Ratings - Summer 2013} \\
\hline & Online quizzes & $\begin{array}{c}\text { Voice over } \\
\text { PPT } \\
\text { Present. }\end{array}$ & $\begin{array}{l}\text { Online } \\
\text { Lectures }\end{array}$ & $\begin{array}{c}\begin{array}{c}\text { Practice } \\
\text { Exams }\end{array} \\
\text { (n) }\end{array}$ & $\begin{array}{c}\text { Practice } \\
\text { Worksheets }\end{array}$ & $\begin{array}{l}\text { Video } \\
\text { Tutorials }\end{array}$ & $\begin{array}{l}\text { Course } \\
\text { Calendar }\end{array}$ & Bulletin Board & E-Mail & $\begin{array}{c}\text { Discussion } \\
\text { Threads }\end{array}$ & Lab Sessions & $\begin{array}{c}\text { Lab Lectures } \\
\text { Videos }\end{array}$ & $\begin{array}{l}\text { Clinical } \\
\text { Videos }\end{array}$ & $\begin{array}{c}\text { Course } \\
\text { objectives }\end{array}$ & $\begin{array}{l}\text { Evolve } \\
\text { Assign. }\end{array}$ & $\begin{array}{c}\text { Readings } \\
\text { Link to } \\
\text { Overview of } \\
\text { chapters }\end{array}$ & Study Guide & Assign. & $\begin{array}{c}\text { Multimedia } \\
\text { Math } \\
\text { Solutions }\end{array}$ & \begin{tabular}{|c|} 
Self- \\
Assessment \\
Tools
\end{tabular} & $\begin{array}{c}\text { Overall } \\
\text { Average }\end{array}$ \\
\hline \multicolumn{22}{|l|}{ Traditional Cohort II } \\
\hline \multicolumn{22}{|l|}{ Adult Health III NURS 2115} \\
\hline $\begin{array}{l}\text { Averages: } \\
\end{array}$ & 5.00 & 5.00 & 5.00 & 4.00 & 4.00 & 5.00 & 5.00 & 5.00 & 5.00 & 1.00 & 5.00 & 5.00 & 5.00 & 5.00 & 4.00 & 5.00 & 5.00 & 4.00 & & 4.00 & 4.53 \\
\hline & \multicolumn{17}{|c|}{ Traditional Cohort III } & & & & \\
\hline \multicolumn{22}{|l|}{ Adult Health I NURS 1111} \\
\hline $\begin{array}{l}\text { Averages: } \\
\end{array}$ & 5.00 & 4.11 & 4.11 & 4.13 & 3.80 & 4.25 & 4.44 & 4.13 & 4.67 & 4.00 & 4.44 & 4.63 & 4.63 & 3.22 & 3.14 & 3.67 & 4.00 & 4.25 & \begin{tabular}{|l|l|}
4.33 \\
\end{tabular} & 4.00 & 4.15 \\
\hline \multirow{2}{*}{\multicolumn{22}{|c|}{ Bridge Cohort III }} \\
\hline \multicolumn{19}{|l|}{ Nursing Care/Women, Child Bridge NURS 2311} & & & \\
\hline $\begin{array}{ll}\text { Averages: } & \\
\end{array}$ & 4.20 & 5.00 & 5.00 & 4.60 & 5.00 & 4.67 & 4.00 & 3.00 & 4.20 & 4.00 & 5.00 & 3.00 & 3.50 & 4.00 & 4.00 & 3.50 & 4.50 & 4.80 & & 3.00 & 4.16 \\
\hline \multicolumn{22}{|l|}{\begin{tabular}{|l|l} 
Nursing Leadership - NURS 2117 \\
\end{tabular}} \\
\hline Averages: & 5.00 & 4.00 & 4.00 & 4.75 & 4.00 & 4.50 & 5.00 & & 5.00 & 5.00 & 5.00 & 5.00 & & 4.60 & 4.00 & 4.33 & 4.75 & 4.75 & 5.00 & 4.67 & $\begin{array}{l}4.63 \\
\end{array}$ \\
\hline & & & & & & & & & & & & & & & & & & & oral & & -1 \\
\hline
\end{tabular}




\begin{tabular}{|c|c|c|c|c|c|c|}
\hline \multicolumn{7}{|c|}{ Phone Interview Summary of Ratings - Summer 2013} \\
\hline & $\begin{array}{l}\text { High speed } \\
\text { access? }\end{array}$ & $\begin{array}{l}\text { Apple } \\
\text { MAC? }\end{array}$ & $\begin{array}{l}\text { Use Smart } \\
\text { Phone? }\end{array}$ & Tablet? & $\begin{array}{l}\text { Difficulty } \\
\text { accessing } \\
\text { course }\end{array}$ & $\begin{array}{l}\text { Was } \\
\text { problem } \\
\text { resolved? }\end{array}$ \\
\hline Both Cohorts & $100 \%$ & $13 \%$ & $53 \%$ & $33 \%$ & $53 \%$ & $50 \%$ \\
\hline
\end{tabular}


Phone Interview Summary of Ratings - Summer 2013 - Mentoring

\begin{tabular}{|c|c|c|c|c|c|c|c|}
\hline $\begin{array}{c}\text { How important } \\
\text { was it to your } \\
\text { success? }\end{array}$ & Time Mgmt. & $\begin{array}{c}\text { Study } \\
\text { Techniques }\end{array}$ & $\begin{array}{c}\text { Test taking } \\
\text { Techniques }\end{array}$ & $\begin{array}{c}\text { Course } \\
\text { Use of Web } \\
\text { resources }\end{array}$ & $\begin{array}{c}\text { Content } \\
\text { Reviews, } \\
\text { Tutoring, } \\
\text { Small Group }\end{array}$ & $\begin{array}{c}\text { Individual } \\
\text { Guidance or } \\
\text { Assistance }\end{array}$ & $\begin{array}{c}\text { Overall } \\
\text { Average }\end{array}$ \\
\hline
\end{tabular}


Phone Interview Summary of Ratings - Summer 2013

\begin{tabular}{cr|r|r|r|r|r|} 
& Advising & Registration & Fee Payment & Bookstore & $\begin{array}{c}\text { Grant } \\
\text { Office }\end{array}$ & $\begin{array}{c}\text { Overall } \\
\text { Average }\end{array}$ \\
\hline Both Cohorts & 3.80 & 4.46 & 4.69 & 4.75 & 4.92 & 4.42
\end{tabular}

